\title{
Post-colonial trade between Russia and former Soviet republics: back to big brother?
}

\author{
Arman Mazhikeyev $^{1} \cdot$ T. Huw Edwards ${ }^{2}$
}

Received: 29 May 2019 / Accepted: 28 September 2020 / Published online: 5 November 2020

(C) The Author(s) 2020

\begin{abstract}
We examine the developments in trade patterns between the former Soviet republics in the years following the initial breakup shock. After a huge fall following the Soviet breakup of the early 1990s, Commonwealth of Independent States (CIS) trade with Russia began improving, and there have been recent formal efforts at Eurasian Economic Integration. This might be taken, a priori, as contrary to the hypothesis of gradual decline in Head, Mayer and Ries (HMR in J Int Econ 81(1):1-14, 2010)—or perhaps as evidence of the power of restored trade agreements, such as the incipient Eurasian Economic Union. We decompose the region's trade into theory-consistent 'gravity' components, in order to analyze dynamic changes in the components since the Soviet era. Despite the sharp falls after 1991, trade in 1995 still shows strong ties, consistent with high dyadic (country pair) components linked to trade specialization. By contrast, in the second decade, the ties (dyads) began to weaken significantly and calibrated trade costs tend to rise, despite attempts at renewed integration. Rather, the sharp improvement in trade volumes was mainly due to the sharp recoveries in GDP levels for both Russia and many of the Central Asian Countries, associated with improvements in the global economy and economic ties with the World (especially with EU and China). We would therefore conclude that the recovery in trade between Russia and Central Asia reflects monadic factors (i.e., the regional economic recovery) and does not contradict the HMR (2010) hypothesis. Nevertheless, further, dynamic analysis shows that there are strong long-run ties within the CIS and Russia, which are not declining, and that sticky post-colonial adjustment does not appear set to eliminate the current bias of trade between these republics.
\end{abstract}

Keywords Trade $\cdot$ Post-colonial ties $\cdot$ Former Soviet Union

JEL Classification F14 $\cdot$ F15 $\cdot$ P33

T. Huw Edwards

T.H.Edwards@lboro.ac.uk

1 University of Lincoln, Lincoln, UK

2 Loughborough University, Loughborough, UK 


\section{Introduction}

When an Empire breaks up, its legacy does not disappear overnight. In the last century, over 200 countries gained independence from their colonizers-especially after World War II. For example, when Algeria gained its independence in 1962, trade with its former colonial master (France) was around $80 \%$ of its total and after 30 years this fell to $6 \%$. Similar patterns were observed throughout the other similar post-colonial relations. This is because colonialism diverts trade away from 'natural' trading partners to colonies/colonizers, but after independence, a former colony (as well as colonizer) will begin to build new economic linkages with countries outside its former colonial relationships. As a result, a post-colonial country like Algeria reduces its economic relations with the metropole (ex-colonizer) in favor of more 'optimal' trade partners and, consequently, the colony's trade gradually begins to decline with its ex-colonizer. Nevertheless, the reorientation can be slow or sudden, depending partly upon the nature of the colonial breakup. Gravity analysis of trade patterns shows that trade between the former colonizer and colonies typically remains raised for decades after independence: for example, in 2004, France continued to account for $24 \%$ of Cote d'Ivoire's exports. Trade with former colonial siblings also retains importance: for example, Ghana's principal export destination is South Africa. These factors decline over time: sometimes rapidly, if independence leads to a nationalist backlash against the former colonist, but more typically, gradually.

In this context, we wish to explore a recent post-colonial experience-namely of the post-Soviet republics, and particularly those who re-joined to the Commonwealth of Independent States (CIS) and its associates, which we term 'CIS+'. Table 1 in the next subsection provides a listing of countries in our study and their memberships of various groupings in the Soviet and post-Soviet eras. Note that we are using the term 'CIS+' because we are including Ukraine, in particular, which left the CIS recently, as well as Turkmenistan, which is not formally a member. ${ }^{1}$ Prior to 1991-92, these were all bound together in a tightly integrated system, which was de facto dominated by (Soviet-) Russia, which we can perhaps view as 'Big Brother' of the post-Soviet republics. Russia remains by far the largest and most powerful member of the CIS+ club. Consequently, we choose to divide the CIS+ group into two: we term Russia the 'metropole' and all other 'CIS+' republics as 'siblings' to each other as they belong to the same former colonial group. We argue this is a valid distinction due to the dominance of Russia within the former Soviet Union (which did, after all, originate in the pre-1917 Russian Empire), and we use

\footnotetext{
1 The CIS members are Azerbaijan (AZ), Belarus (BY), Kazakhstan (KZ), Kyrgyzstan (KG), Moldova (MD), Russia (RU), Tajikistan (TJ) \& Uzbekistan (UZ). Turkmenistan (TM) and Ukraine (UA) are associates, which makes it 'CIS+'. Regarding Ukraine, however, since our data set covers the period before the Crimea event, we consider Ukraine to have been one of the closest allies to Russia. Sadly we do not have the appropriate data for Armenia, which is a CIS member. The Baltic States (Latvia, Lithuania \& Estonia) refused to join the CIS and kept themselves distant from Russia. Georgia withdrew itself from CIS in 2008 due to its conflicts with Russia. Thus, we do not include the latter four in the 'CIS+' group.
} 


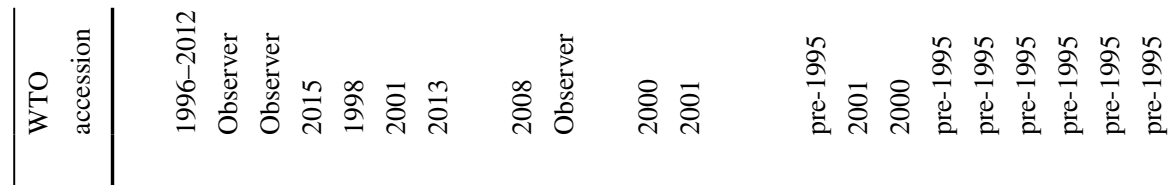

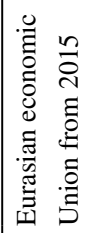

点

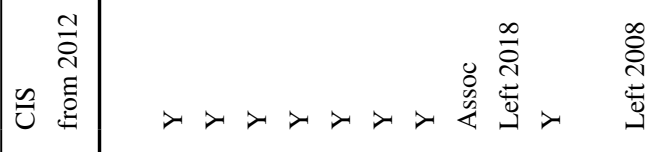

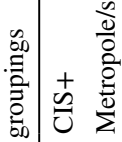

$\frac{0}{0}$

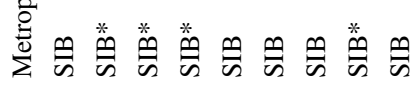

땅

乞

$\lambda \succ \lambda \succ \lambda \succ \lambda \succ \lambda$

兽 


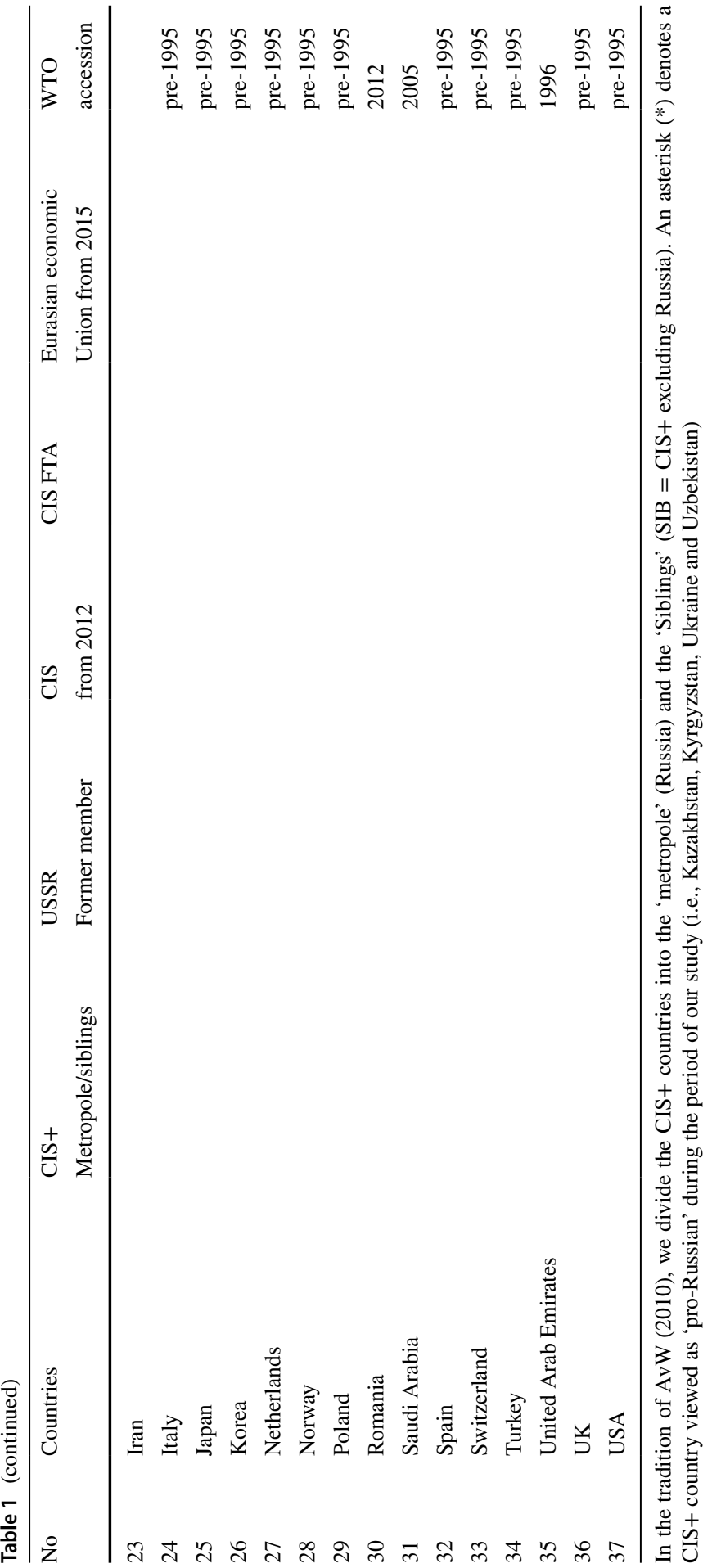


this division of the CIS+ into metropole and CIS+ siblings - 'SIB' - in much of our analysis below.

Soviet-era integration was very tight, especially given the lack of freedom to trade outside the Union of Soviet Socialist Republics (USSR). By contrast, pursuit of standardization and scale economies within the USSR led to integration of enterprises and distribution systems, under the control of Moscow-based ministries, the direction of transport infrastructure, strict control over external trade (semi-autarky for the USSR) and the spread of Russian-speakers as a diaspora across the republics, all of which integrated the republics tightly. In the post-Soviet period, and particularly since the economic stabilization after 2000, Russia has continued to seek close hegemonic ties, particularly with the relatively isolated and slower-reforming autocracies of Central $\mathrm{Asia}^{2}$ in the form of a revival of a fledgling Eurasian Economic Union-formed by treaty in 2014, successor of the Eurasian Custom Union launched in 2011, whose current membership is Russia, Belarus, Kazakhstan, Armenia and Kyrgyzstan — as a more authoritarian rival to the European Union.

There are obvious limitations to data comparisons between the Soviet and postSoviet eras. Nevertheless, the early breakup was very marked. Djankov and Freund (2002a, b) document that in 1990 all Soviet republics apart from Russia sent more than $80 \%$ of their exports to other Soviet republics, ${ }^{3}$ while by 1996 most republics had undergone a significant realignment. This early breakup was clearly a major disruption, but for reasons of data continuity (pre-1991 trading prices were clearly distorted within the Soviet system, while after 1991 there were several years of hyperinflation), we prefer to focus our study on the period after this, from 1995. Looking at the former Soviet republics other than Russia, the share of trade with other ex-Soviet republics in this early breakup period was quite variable, with the Baltic States, whose breakup with the Soviet Union was hostile, among those seeing the sharpest falls, but also Tajikistan, Armenia, Ukraine and Azerbaijan. Moldova and Belarus, perhaps for geo-political but also economic reasons, continued their alignment with the other former Soviet republics.

Our study focuses on the period subsequent to this. We acknowledge difficulties in deriving consistent data between the pre-1995 and post-1995 periods and focus on the latter. Most notably, during the post-1995 period, unlike the earlier period, trade started recovering sharply between former Soviet republics. For example, trade between the Central Asian former Soviet republics and Russia (the metropole), during the 1995-2014 period increased almost 11-fold from its post-Soviet nadir (from 2.1 to 23 billion U.S. dollars) and ex-Soviet republics' shares in each other's total bilateral trade actually increased. ${ }^{4}$ The more Western republics have perhaps not moved as sharply back toward Russia-indeed, the Baltic States, Georgia, Moldova and, latterly, Ukraine, have begun orienting toward Europe-but the resumption of

\footnotetext{
${ }^{2}$ Former Central Asian USSR members are Kazakhstan, Kyrgyzstan, Tajikistan, Turkmenistan \& Uzbekistan.

${ }^{3}$ Russia itself was a partial exception, primarily for the statistical reason that it is by far the largest of the former Soviet republics, so 'other Soviet republics' was a smaller category in the case of Russia.

4 Source: COMTRADE.
} 
former Soviet trade ties is still apparent. This compares to the steadier decline in post-colonial ties indicated by Head, Mayer and Ries' (HMR 2010) classic study, which examined the effect of independence on post-colonial trade of over 220 countries (including post-Soviets) between 1948 and 2006. Their work suggests that typically trade between a colony and its metropole (colonizer) erodes by $65 \%$ after 40 years passes since independence of the colony. Hence our paper starts by analyzing whether the sharp recovery in trade volumes between ex-Soviet countries since 1995 reflects a return to old ties, perhaps driven by policies (such as the various Free Trade Agreements, leading toward the institution of the recent Eurasian Economic Union), or whether the primary driver of recovery is simply the recovery of GDP, given stabilization and a recovery of oil prices after 1998. We review this below, although a first answer is that it is more of the second (recovery of output) than the first.

We do, however, investigate these issues more thoroughly in the rest of the paper. In particular, we develop and modify the gravity analysis of post-colonial ties developed by HMR (2010), to analyze post-Soviet relationships. In doing this, we find considerable heterogeneity between the post-Soviet republics. In this paper, we aim to strike a balance between acknowledging this heterogeneity, on the one hand, and seeking evidence of common trends, on the lines of other studies of post-colonial trade, on the other. We particularly favor the idea that 'clubs' of countries closer to Russia and further from it (politically and economically, rather than geographically) may help us understand the developments in the region.

In the rest of this section, we analyze the stylized facts of trade flows between the former Soviet republics. In Sect. 2, we discuss a basic gravity framework, following from HMR (2010), while in Sect. 3 we then start interpreting this in terms of potential factors which might influence post-colonial persistence in the former Soviet case. Sections 4 and 5 outline the data and discuss results, while Sect. 6 concludes.

\subsection{Stylized facts of post-Soviet trade}

The Soviet Union (USSR) was formally dissolved on December 26, 1991, ending a 70-year experiment in centrally planned integration between and within the republics. Table 1 lists all the countries in our study-these include 12 out of the 15 former members of the USSR. ${ }^{5}$ The breakup was with varying degrees of hostility: in the first instance (de facto prior to the formal Soviet breakup), the three Baltic States (which had been occupied by Stalin after the Second World War) broke more or less completely with Russia (Rajasalu 1995), leading to the immediate imposition of sizeable trade barriers. These states never returned to any post-Soviet club, and eventually joined the European Union. Other states formed the relatively loose Commonwealth of Independent States (CIS), as listed in Table 1. This failed to prevent some conflicts between states, notably with the 'metropole' of the former Soviet Union (Russia), and eventually Georgia and recently Ukraine left the CIS.

\footnotetext{
5 The three missing members are Armenia, Estonia and Latvia.
} 
Despite the attempts to maintain economic ties, the demise of planning links, imposition of different currencies and regulatory regimes and general economic turbulence led to huge drops in trade between the republics. For example, an early study by Djankov and Freund (2002a, b) compared the share of trade of former USSR states before and after the USSR collapse in 1991-92, showing that between 1990 and 1996 the internal trade among ex-USSR states declined by about $40 \%$, with largest drops in Estonia (65\%)—which left the CIS and had trade barriers imposed-and Armenia (53\%), which had a conflict with Azerbaijan, and the smallest drops in Belarus (9\%) and Moldova (20\%). For Russia the share of inter-republican trade declined from 65 to $23 \%$. Another study by Sinitsina (2012) reported a tenfold decline in internal trade between Central Asian republics and Russia during the first decade after the Soviet breakup.

None of the former Soviet republics was a member of the WTO at its inception in 1995. Crucially, Russia only gained full membership in 2012, Ukraine in 2008 and Kazakhstan in 2015. Azerbaijan, Belarus and Uzbekistan still have observer status (or in Belarus' case, 'strategic focus'), while Turkmenistan has no WTO ties at all. An implication of this is that these countries generally took into the twenty-first century to liberalize trade, and some have yet to do so to the WTO's satisfaction.

It is worth noting that, in the period after 2000, attempts were gradually made to reestablish economic integration within the former Soviet area (and this is one of the topics in this paper): however, a number of countries chose not to participate-not just the EU-joining Baltic States, but also Georgia, which left the CIS in 2008 after a Russian invasion in support of rebels, and Ukraine, which chose a pro-EU path after the fall of Viktor Yanukovych, and eventually left the CIS in 2018, four years after the Russian takeover of Crimea.

Nevertheless, for those countries choosing to return to a Russian-linked sphere, integration included the development of a formal CIS Free Trade Area from 2012, and, for just four countries on our list (plus Armenia), the more tightly integrated Eurasian Economic Union from 2015, which bills itself as an integrated single market of 180 million people.

\subsection{Analysis in terms of post-colonial ties}

The decline in post-Soviet trade following 1991 can be interpreted in comparison with other colonial breakups, as emphasized in the HMR (2010) findings of postcolonial trade erosion in colony-metropole trade relations. As a key benchmark for post-colonial trade erosion, HMR (2010) utilized a sophisticated, time-varying adaptation of Anderson and van Wincoop's (AvW 2003) multilateral trade resistances, and found that a country's trade with the colonizer, typically, erodes by $65 \%$ after 40 years of independence. While the ex-Soviet republics were not formally colonies of Russia during the era of the USSR, Russia was at least informally dominant. Thus, we can view the relationship of the CIS and Russia as a highly specific application of the HMR (2010) study of post-colonial ties, albeit we prefer to talk of the 'metropole' (Russia) and 'siblings' ('SIB,' i.e., the rest of CIS+ excluding Russia). 
Defining 'CIS+' as slightly broader than the Commonwealth of Independent States (as listed in Table 1), still including Ukraine plus associate member Turkmenistan, changes in trade patterns between CIS+ countries in the post-Soviet period are presented in Fig. 1. The first line (the blue line) is the siblings' (CIS+ other than Russia) exports (X) to Russia (RUS) divided by the same countries' export to Germany $(\mathrm{DEU})^{6}$, i.e., $\left(X_{R U S} / X_{D E U}\right)$. By taking trade ratios, we are avoiding possible misinterpretation of actual trade changes which could happen if we only look at value changes in exports and imports. The second line (the red line) is CIS+ siblings' exports (X) to other CIS+ siblings (i.e., other than Russia) divided by their export to Germany (DEU), i.e., $\left(X_{S I B} / X_{D E U}\right)$. However, in interpreting these trade patterns, we need to compare this with the relative GDPs of Russia to Germany (the dotted line): this ratio started rising (along with the oil price) from 1998 on, and the average export ratio gradually approaches the GDP ratio (while still exceeding it) over the whole period. Figure 1 shows that export flows from the CIS+ siblings to Russia were declining in the first decade as expected but then they have been restored in the second decade. We also observe that the GDP ratio was rising during 2000s which might explain part of the trade persistence with the Big Brother. Changes in exports among the siblings look similar to those with Russia, strongly reflecting the GDP ratio changes.

Separately, we construct the ratios for incoming trade flows in Fig. 2. The first line (the blue line) is CIS+ siblings' ('SIB') imports (M) from Russia (RUS) divided by their imports from Germany (DEU), i.e., $\left(M_{R U S} / M_{D E U}\right)$ and the second line (the red line) is CIS+ siblings' imports (M) from the other siblings (SIB) divided by their imports from Germany (DEU), i.e., $\left(M_{S I B} / M_{D E U}\right)$. Unlike Fig. 1 for exports, Fig. 2 shows that the average import from Russia compared to imports from Germany remains remarkably flat, after an initial uplift in 1996. The import ratio for siblings' trade almost mirrors the former import ratio, especially in the first part, showing a sudden decline in 1996, then flat until 2007, with a 'U-shaped' dip, most likely caused by the financial crisis of 2008 , followed by a renewed increase.

One question is whether, in fact, we are looking at post-colonial trade persistence which contradicts the HMR (2010) general findings. ${ }^{7}$ To obtain the trade ratios we use the same bilateral trade data set obtained from World Integrated Trade Solution (WITS). An important caveat here is that we cannot derive the ratios for the initial (1991-94) trade collapse between the regions, due to a lack of good data. ${ }^{8}$ Note that this is not inconsistent with observations of the even sharper trade realignment of the Baltic States (Rajasalu 1995), though in those cases the fall was even more acute, due to trade sanctions in response to their decision to leave the Soviet Union and not to enter the CIS. Indeed, both the Russian and CIS+ economies endured huge trade

\footnotetext{
${ }^{6}$ Germany has been chosen for comparison, because it is one of the sizeable economies outside the Former Soviet Union area but it is similar to Russia in GDP size and also in its geographic distance to CIS+, unlike other alternative, China.

7 Although there is a possibility that efforts at reintegration may have affected this: something which we seek to test.

${ }^{8}$ Data on the initial collapse are unreliable, due to issues of valuing output and trade when products are of questionable quality and prices initially were constrained at far from market prices.
} 


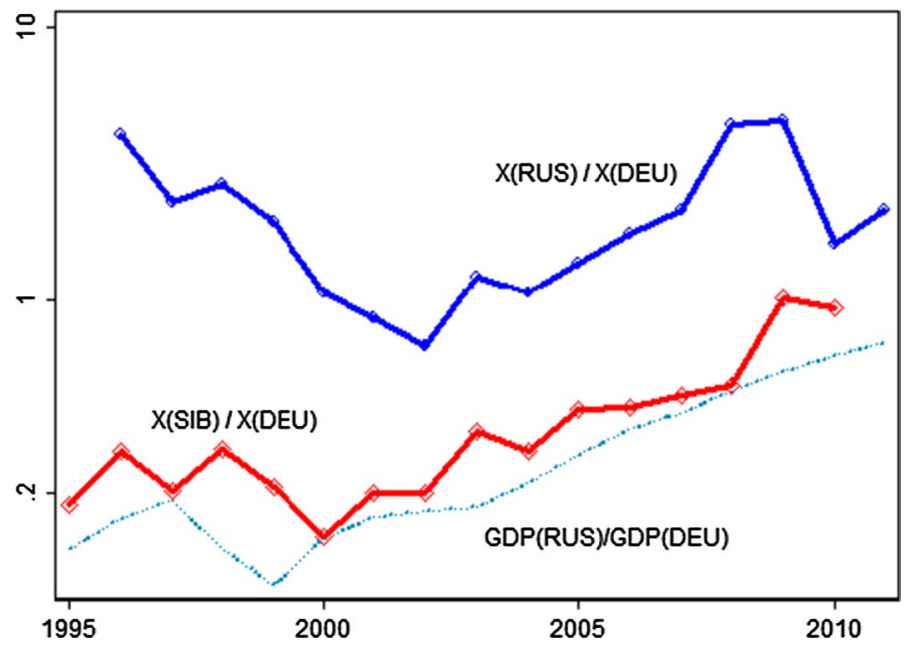

Fig. 1 CIS+ Sibling States' export flows to Russia and to the other siblings, compared to those to Germany. Source: Authors' calculations using trade data from WITS database

and production hardships with the Soviet collapse and subsequent hyperinflation in 1991-95. In fact, the disruption of what had been integrated supply chains by managerial independence, the introduction of border controls and initial currency convertibility issues, is often cited as a major cause of the collapse of output across the former Soviet Union in this period (see, for example, Linn 2004).

In order to examine changes in the relative orientation of trade presented in Figs. 1 and 2, it is useful to look at trade ratios of each individual CIS+ sibling member with Russia. These are shown in the two parts of Fig. 5 in 'Appendix.' Most CIS+ countries share similar trade patterns to those shown in Figures 1 and 2; however, there is some heterogeneity. Some CIS+ countries (Kyrgyzstan, Uzbekistan and Tajikistan) had above average export ratios toward Russia, while the oil exporters such as Kazakhstan, Turkmenistan and Azerbaijan had reoriented their exports toward the rest of the World (non-USSR). Country-level import ratios suggest that only Uzbekistan and Kyrgyzstan (which are isolated from Europe) and Belarus (which clung faithfully to Soviet standards) were above average in terms of relative import share from Russia, while Ukraine and Moldova had joined Lithuania in shifting imports toward Germany.

\section{Theoretical framework and methodology}

Although it started as a purely empirical model, in recent decades, the gravity model has been given a sound theoretical grounding, associated with various trade models: in the case of the Armington model, Anderson and van Wincoop's (AvW 2003) paper is seminal, while Bergstrand (1989) links gravity to Krugman's 'love of variety' model. Deardorff (1998) produced a Heckscher-Ohlin derivation, while Eaton and Kortum (2002) adopted a Ricardian approach. More 


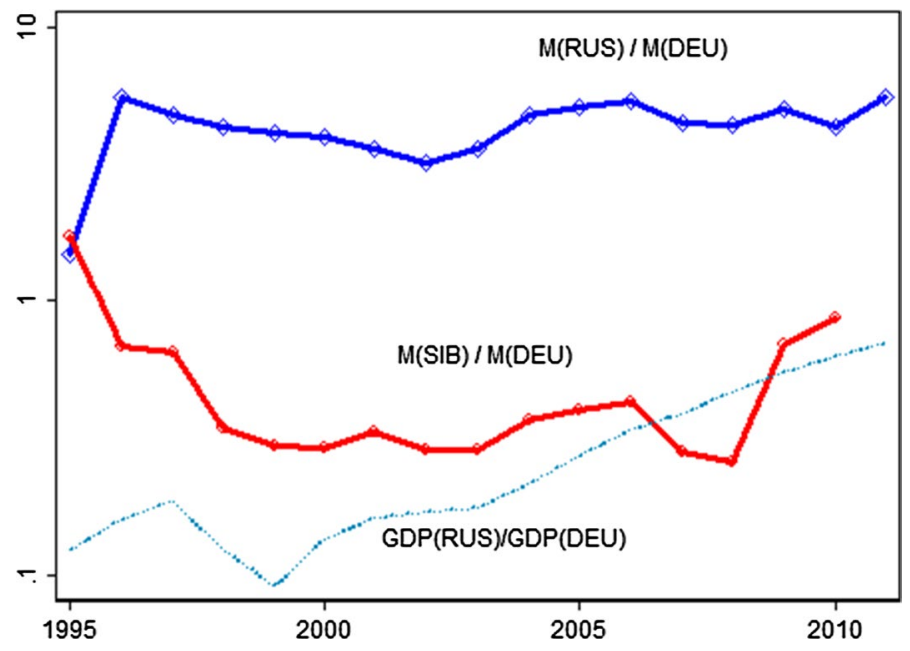

Fig. 2 CIS+ Sibling States' import flows from Russia and from other Siblings, compared to those from Germany. Source: Authors' calculations using trade data from WITS database

recent trade theory developments are incorporated by Chaney (2008), Helpman et al. (2008) and Head and Mayer (2014).

In this paper, we analyze post-Soviet trade flows between the countries which we term 'CIS+' - especially between the metropole, Russia and the siblingsfrom the perspective of the structural gravity framework that explains trade flows in terms of 'monadic' (country-specific) and 'dyadic' (country-pair-specific) factors. This can be summarized by a standard panel gravity equation for trade between countries $i$ and $j$ in year $t$ :

$$
x_{i j t}=g_{t} m_{i t} n_{j t} d_{i j t} .
$$

In this framework, $x_{i j t}$ is the trade flow from $\mathrm{i}$ to $\mathrm{j}$ at time $\mathrm{t}$ which is equal to $g_{t}$, a 'global' factor (such as the value of global trade), which can usually be proxied with a series of year dummies; $m_{i t}$ and $n_{j t}$ are the 'monadic' (or country-specific) factors, comprise economic output (GDPs) and overall openness to trade (as measured in the form of 'multilateral trade resistance' by $\mathrm{AvW}$ (2003); and $d_{i j t}$ is a set of 'dyadic' factors, which refer to country-pair-specific factors, such as transport costs (related to distance), colonial and language ties and a common border, which are statistically and economically significant. Using a variety of methods, we analyze dynamic changes in the components over the period 1995-2011, differentiating between monadic (country-specific) and dyadic (country-pair-specific) factors.

Looking first at the role of monadic factors: in the first decade after Soviet breakup, these were weak, and explain much of the initial collapse. Economic disruption and the weakness of primary product prices (Russia, Azerbaijan and much of Central Asia all being dependent on primary product exports, while Ukraine was dependent upon pipeline rents, at least until after the Orange Revolution of 2004-05), meant that GDP in both Russia and the CIS+ siblings was 
well below Soviet levels. Indeed, once we correct for the overall effects of the initial fall in economic output, the dyadic pair-specific component (including Soviet built socioeconomic CIS+-Russia ties) in trade was still strong in the first decade of CIS+ independence, in the sense that Russian-sibling trade remained well above the distance-adjusted GDP ratio. However, in the second decade, our analysis shows that these dyadic ties were weakening significantly (in line with the HMR (2010) finding of eroding post-colonial trade relationships). Against, this, GDP in most of the CIS+ states began to improve fast after 2000, as economies were stabilized and as primary export prices recovered.

In analyzing the relationships between the CIS+ siblings and the metropole (Russia) but also relationship of the siblings with each other, we need to note that there is a good deal of heterogeneity in the post-colonial paths of these countries. In this paper, we aim to strike a balance between acknowledging this heterogeneity, on the one hand, and seeking evidence of common trends, on the lines of other studies of post-colonial trade, on the other hand. We particularly favor the idea that 'clubs' of countries closer to Russia and further from it (politically and economically, rather than geographically) may help us understand the developments in the region. Indeed, irrespective of which of the various theoretical foundations is chosen, all these studies broadly conform to the gravity model expressed in (1). Further to provide more insight into our regression results, we restate (1) using AvW's (2003) Armingtonbased structural gravity form:

$$
x_{i j t}=\frac{y_{i t} y_{j t}}{\sum_{i} y_{i t}}\left(\frac{\tau_{i j t}}{P_{i t} P_{j t}}\right)^{1-\sigma},
$$

where on the left side, $y_{i t}$ is output in i, $y_{j t}$ is expenditure in $\mathrm{j}, \tau_{i j t}$ is the bilateral iceberg type trade cost and $P_{i t}$ and $P_{j t}$ are exporter and importer multilateral resistances (CES aggregate prices-see below) at time t.

\subsection{The monadic components}

The monadic components, $m_{i t}$ and $n_{j t}$, are the sets of unique attributes that are only in the possession of $i$ or $j$, respectively, at time t explaining the trade flow between the pair. The monadic component of any i comprises positive (GDP, $y_{i t}$ ) and negative (local composite price index of 'multilateral resistance,' $P_{i t}^{1-\sigma}$ ) attributes, and can be written as:

$$
\begin{gathered}
m_{i t}=\frac{y_{i t}}{P_{i t}^{1-\sigma}} . \\
n_{j t}=\frac{y_{j t}}{P_{j t}^{1-\sigma}} .
\end{gathered}
$$


Theoretically speaking, local output, $y_{i t}$, is equal to the sum of gross consumption $c_{i j t}$ of $i$ 's produce across all countries $j$ (including $i$ ) at a price $\left(p_{i j t}\right)$ at time that differs from $j$ 's domestic price level by the inclusion of a trade cost $\left(\tau_{i j t}\right)$ :

$$
y_{i t}=\sum_{j} c_{i j t} p_{i j t}=\sum_{j} c_{i j t} p_{i t} \tau_{i j t} .
$$

Region $j$ 's economic size at time $t\left(y_{j t}\right)$ is calculated analogously. It is common practice in a gravity analysis to proxy economic size using the nominal GDP of the country, or by collecting bilateral trade flows by either $i$ or $j .{ }^{9}$

An important component of Eq. (3) is the multilateral resistance to trade (MRT) term, the central contribution of AvW (2003). The outward trade resistance of exporter region $\mathrm{i}$ at time $\mathrm{t}, P_{i t}$, is price index that takes into account the weighted aggregate values of observable traded costs $\left(\sum_{j} \tau_{i j t}\right)$ and income share $\left(\sum_{j} \theta_{j t}^{\frac{1}{1-\sigma}}\right.$, where $\left.\theta_{j t}=\frac{y_{j t}}{\sum_{i} y_{i t}}\right)$ across all possible import partners and takes the form of CES unit cost functions:

$$
P_{i t}=\left(\sum_{j} P_{j t}^{1-\sigma} \theta_{j t} \tau_{i j t}^{1-\sigma}\right)^{\frac{1}{1-\sigma}}
$$

Here, $\sigma$ is the CES elasticity of substitution between domestic and imported goods. The parameter should be larger than one, but exact values may change as preferences and trade opportunities change. Some studies try to estimate it (e.g., Chen and Novy 2012) or calibrate it (e.g., Balistreri and Hillberry 2008) but most studies introduce it exogenously by assigning a level to it. The inward trade resistance of region $j$ at time t, $P_{j t}$, is derived in similar fashion just by replacing $i$ and $j$ in (6). Both inward and outward MRT terms are not directly observable, though gravity studies provide methods to construct them (see Anderson and Yotov 2010).

\subsection{The global component}

The global factor $\left(g_{t}\right)$ is the scale of the global economy, which plays a role of a scale parameter in the gravity equation, and it is equal to the sum of nominal incomes collected either by $\mathrm{i}($ or $\mathrm{j}$ ) at time $\mathrm{t}$ :

$$
g_{t}=\frac{1}{\sum_{i} y_{i t}}=\frac{1}{\sum_{j} y_{j t}} .
$$

In the era of globalization and intense integration, a country builds more trade linkages with other countries (through liberal reforms, trade agreements or trade unions, etc.) and becomes a part of bigger economy (global or regional economy). This way

\footnotetext{
9 This would also require domestic trade data.
} 
a country whose economic size is $y_{j}$ forms a part of World economy size $\left(\sum_{j} y_{j}\right)$ and depending on the countries relative to World economic size and nature of networking, changes in (2) can affect the left-hand side of (1) either positively or negatively.

\subsection{The dyadic component}

The dyadic component $\left(d_{i j t}\right)$ is a trade cost associated with physical and psychic distances (and quality) in each unique (specific) ijt set:

$$
d_{i j t}=\tau_{i j t}^{1-\sigma}
$$

where trade costs, $\tau_{i j t}=\sum_{m}\left(z_{i j t}^{m}\right)^{\gamma_{m}}$, comprise the combined effect of a series of bilateral physical (geographic distances, transport mode, quality of transport infrastructure) and psychic (or non-physical) trade barriers (tariffs, quotas, language, etc., indexed $m$ ), and are assumed symmetric in both directions, and of 'iceberg' form (Samuelson 1952). The geographic distance between trading countries $i$ and $j$ commonly serves as a proxy for transport cost. Psychic distance is not directly observable, but can be proxied by a set of attributes (such as language barrier, adjacency and colonial history), which are commonly found to important in gravity-based studies. For instance, HMR (2010) used year dummies to capture the growing effect of independence on trade relations between a former colony and metropole. However, some dyadic barriers (such as tariffs) can change from year to year while other types of barriers (geographic distances) would be constant.

\subsection{Capturing the dyadic component: the Tetrad method}

Because we are interested in the time-varying effect of independence on trade between a metropole (colonizer), colony and siblings (other colonies), in the Soviet Union context, apart from standard gravity analysis, it is sensible for us to adopt the so-called Tetrad method. HMR (2010) show that by taking a ratio of ratios of bilateral trade flows (i.e., a tetrad of the flows) in the following form we can obtain $t_{(i l)(j k) t}$, a tetrad of the dyadic components:

$$
t_{(i l)(j k) t}=\frac{x_{i j t} / x_{i k t}}{x_{l j t} / x_{l k t}}=\frac{d_{i j t} / d_{i k t}}{d_{l j t} / d_{l k t}},
$$

where $x$ denotes bilateral trade flow and additional subscripts ( $k$ and $l$ ) stand for two particular reference countries. This is well explained in HMR (2010) study but essentially we can understand (9), if we replace $x$ 's with gravity components on the r.h.s. of (1), the monadic and global constant components cancel out leaving $\frac{d_{i j} / d_{i k}}{d_{l j} / d_{l k}}$ alone. Because $d_{i j t}=\tau_{i j t}^{1-\sigma}$, and given that $\sigma$ is the same across all countries, then (9) is also a measure of trade costs (both observable and unobservable costs) relative to their level at two chosen reference countries $(l, k)$ : 


$$
\tau_{(i l)(j k) t}=\left(\frac{x_{i j t} / x_{i k t}}{x_{l j t} / x_{l k t}}\right)^{\frac{1}{1-\sigma}}=t_{(i l)(j k) t}^{\frac{1}{1-\sigma}} .
$$

More detailed discussion on this method is in HMR (2010).

\section{Factors behind the potential trade persistence of the Soviet ties}

In this paper, we are testing whether post-Soviet Russian-other CIS+ sibling ties broadly conform to the usual post-colonial pattern of gradual decline, led by rising relative trade costs between former colonizer and its colonies. However, no group of countries is identical to any other, and we therefore need to take careful account of other factors - monadic and dyadic — which might affect the dynamics of trade change, given the mass geography of the region.

\subsection{Monadic factors}

\subsubsection{Patterns of GDP}

We would like to start with some key concepts. Trade volumes react to changes both in trade costs and in economic activity. Studies of the erosion of post-colonial ties (such as HMR 2010) normalize for changes in economic activity by utilizing a gravity framework, which eliminates the effect of GDP changes. We need to bear in mind that the recovery in trade volumes between Russia and CIS + siblings will, in part, be responding to the recovery in economic output of the two regions between 1998 and 2008, in turn reflecting a global commodities boom and a bounce-back from the initial disruption of the Soviet breakup.

We note that GDP growth, when it occurs in both the exporter and importer countries, has a compounded effect on bilateral trade volumes. For example, if we use the simpler format in Eq. (2), where the elasticity of trade volume with respect to both exporter and importer countries is set at 1, then if GDP of both halves (which is not a bad approximation of the post-Soviet collapse) then we might expect trade between the two countries to fall by $75 \%$, while if exporter and importer GDPs subsequently double again, bilateral trade will quadruple. ${ }^{10}$ Since gyrations of GDP in the post-Soviet era have been extreme, we would expect to have to correct for these large compounded effects, before we can actually start working out what is happening to post-colonial trade bias.

\footnotetext{
10 This crude calculation needs qualifying where the rest of the World is also growing, as multilateral resistance terms will change. However, the gyrations in the post-Soviet economies since 1991 have been dramatic compared to the rest of the World, and so we would expect even larger swings in trade between them.
} 


\subsubsection{Multilateral resistance and the lack of alternative trading partners}

Remoteness and inaccessibility are also important factors in determining trading patterns, especially in the context of landlocked former-USSR countries and even some remote parts of Russia. Any factor which raises trade costs on one route will lower trade (negative dyadic factor), but at the same time raise the overall price level within the nation concerned (monadic factors offsetting the effects of raised trade costs with any one partner). This is worth bearing in mind in the section below, as we discuss dyadic factors.

\subsection{Persistent non-policy dyadic factors}

It is worth noting that all of the CIS + countries were colonized by Russia gradually well before the Russian Revolution. ${ }^{11}$ The number of Russian colonists in Siberia rose to 2.7 million by 1850 . The Caucasus was largely gained following the Crimean War. In Central Asia, Tashkent fell to the Russians in 1865. The Trans-Siberian Railway was built between 1891 and 1916, while the Russians had also built railways into their Central Asian territories before the First World War. With the railways came settlement: the 1897 Census shows ethnic Russians were already $12.8 \%$ of the population of Kazakhstan in 1900, with Russian farmers settling in Northern Kazakhstan in the 1890 s. This rose to over $20 \%$ in 1926 , and $40 \%$ in 1939 , as Stalin's forced movement of Soviet peoples took hold.

Hence, historically, we are looking at regions which began integrating with Russia in the last decade of the nineteenth century, but whose integration was accelerated by the Soviets. Consequently, colonial ties can be seen as predating the Soviets, but were strengthened during Soviet rule.

\subsubsection{Isolated and landlocked location}

The CIS + countries occupy a vast and mostly sparsely populated, landlocked area. In this regard, the most extreme cases are the Central Asian states, which are not only landlocked, but also bounded to the South and East by mountains and deserts. Limao and Venables (2001) estimate that overland transport costs of goods averaged $\$ 1.380 / 1000 \mathrm{~km}$, almost 10 times higher than by sea $(\$ 190 / 1000 \mathrm{~km})$, and Carrere and Grigoriou (2007) found an additional transport cost, freight cost is $\$ 500 / 1000 \mathrm{~km}$. The easiest overland trade routes are north-westward into Russia, and Russian goods will face less competition from other countries, simply because the Central Asian states will face even higher transport costs to get the goods anywhere else. In AvW's (2003) terminology, the multilateral resistance price is high in these countries, which means that trade with Russia will be greater than might otherwise be inferred from size and distance.

11 A concise summary of this is provided at http://www.fsmitha.com/h3/h47-ru4.htm. 
Raballand (2003) found that the trade of landlocked former Soviet countries, compared to coastal ones, fell by $80 \%$ during $1995-1999$ period, so landlocked Central Asians, if they wanted to trade, had to negotiate with bordering coastal Russia, to access its sea transport channels (Carrere and Grigoriou 2007). Djankov and Freund's (2002a, b) study, which focused on border effects on trade, estimated that (non-physical) trade barriers imposed by coastal Russia to landlocked Central Asia were very high compared to trade barriers imposed by coastal states to landlocked ones in the OECD area.

A key implication of this is that, even though Russian-Central Asian trade may have been inflated by excessive Soviet era integration (and trade barriers with the rest of the World), these countries, unlike many other former colonial groupings, can still be seen as natural trading partners, and hence we would expect a smaller longrun decline.

For other republics: Armenia is landlocked and has a relatively isolated mountain location, especially given its poor relations with its immediate neighbors (Turkey and Azerbaijan). Even for Azerbaijan, the political effects of conflicts in Georgia and Chechnya will have deterred trade.

In this regard, the more Westerly former Soviet republics had much easier contact, at least with Europe. The Baltic States, which joined the EU, not the CIS, have easy sea links to the West. Ukraine and Moldova also border the EU, as does Belarus, although in this latter case political isolationism is an important offsetting factor.

\subsubsection{Transport infrastructure patterns}

The former Soviet republics have dated transport connections, dominated by Soviet transport infrastructure connecting Russia and the CIS+ siblings. Most traded and transit goods of both regions rely on those railroads (for the Central Asian republics, for example, it is about $90 \%$ ). The railroad net mostly covers western Russia and Kazakhstan. Carrere and Grigoriou (2007) argue that infrastructure and railroads built during the Soviet era are an important factor in determining with whom Central Asian republics will choose to trade (meaning with Russia and the CIS+ Siblings). ${ }^{1213}$ Further West, Ukraine and Moldova, Belarus, Azerbaijan and Georgia have begun to benefit from EU neighborhood investments in transport and port infrastructure, particularly under the Eastern Partnership Transport Panel, established in $2011 .{ }^{14}$ It is worth noting that the imposition of national borders can increase delays and hence worsen infrastructure: Djankov and Freund (2002b), found that between 1989 and 1996, train speeds increased by an average of $2 \%$ between Russian regions,

\footnotetext{
12 Source: Eurasian Development Bank (2009)

13 According to EDB, the main trade channels of Central Asia and Russia include the Trans-Asian-Railway (Uzbekistan-Kyrgyzstan-Tajikistan-Kazakhstan-Russia-Ukraine); the Trans-Siberian Rail channel (Russia-Mongolia-China); the East-Trans-Asian-Railway (Uzbekistan-Tajikistan-Kyrgyzstan-Kazakhstan-China).

14 https://ec.europa.eu/transport/themes/international/european_neighbourhood_policy/eastern_partn ership/transport-panel_et.
} 
but slowed by an average of 5-6\% between Russian regions and other former Soviet republics.

\subsubsection{Migration and language ties}

There was considerable migration between what are now the CIS+ republics before and during Soviet times. For example, even now each 10th citizen of Russia is Central Asian (17.8 million) and each 10th Central Asian citizen is Russian (6.72 million) (Central Intelligence Agency 2018). The majority of this migration occurred during the Soviet era, and was permanent enough for at least one generation to be born in their new adopted homes (Table 2). These migrant diasporas create longlasting social and cultural connections between the regions and have an important impact on the economic and political relationship between Russia and the Central Asian countries.

Despite earlier migration (Peyrouse 2008), it was during the Second World War and Khrushchev's Virgin Lands Campaign that the Russian population in Central Asia rose from 20.6 to 42.7\% (Anderson and Silver 1990), although after 1980 - and especially after the Soviet collapse- this began to reverse. Between 1979 and 1999, the share of Russians in Kazakhstan dropped from 40.8 to 30\%; in Kyrgyzstan from 25.9 to $12.5 \%$; in Uzbekistan from 10.8 to $3 \%$; in Tajikistan from 10.4 to $1 \%$ and in Turkmenistan from 12.6 to $2 \%$. These were mostly skilled, educated and young people. Since 2000, there has been emigration of indigenous Central Asians to Russia-mostly temporary workers from the poorer Central Asian countries. According to Sinitsina (2012), in the 2000s, 12.3 million migrated legally and 5-8 million illegally from the Central Asian countries to Russia, taking advantage of a visa-free border passage and contacts with existing diasporas.

In Ukraine, over 8 million people, or $17 \%$ of the population, identified themselves as ethnically Russian in the 2001 census, with the Russian population being concentrated in Crimea (since seized by Russia) and the Donbass region (now held by proRussian rebels). Likewise, in Moldova, the Russian-speaking region of Transnistria is de facto independent. Oil-rich Azerbaijan traditionally had a large ethnic Russian population, although this declined sharply from 392,000 in 1989 to 142,000 a decade later and 199,000 in 2009 (see Azerbaijan State Statistical Committee, 2009).

Language In Central Asia, Russian is a lingua franca in diplomatic and business meetings with Russians. Even though the Central Asians have their own titular languages, Russian is still popular in everyday life, the media, in education and employment, bringing the Central Asian nations closer to Russia. Currently, $70 \%$ of Central Asian citizens (Russians or indigenous Central Asians) make use of the Russian language in their daily life rather than other Central Asian languages; however, this percentage varies across countries. In 1989, the proportion speaking good Russian varied from $64 \%$ in Kazakhstan to $27 \%$ of the population of Uzbekistan.

After independence, local language policies aimed to reduce the use of the Russian language: especially in Uzbekistan, Turkmenistan and Tajikistan. For instance, Turkmen schools that taught in the Russian language declined by $71 \%$ by the end of 90s. By contrast, Kazakhstan and Kyrgyzstan have a relatively higher population of 
Table 2 Share of Russians and Central Asians in 1980 and 2007 (in \% terms) in Central Asian Countries' population Source: Goscomstat and Sinitsina (2012). Numbers with * mean Central Asians living in Russia

\begin{tabular}{|c|c|c|c|c|c|c|}
\hline \multirow[t]{2}{*}{ Countries } & \multicolumn{3}{|l|}{1980} & \multicolumn{3}{|l|}{2007} \\
\hline & Titular & $\begin{array}{l}\text { Russians/Cen- } \\
\text { tral Asians }\end{array}$ & Others & Titular & $\begin{array}{l}\text { Russians/Cen- } \\
\text { tral Asians }\end{array}$ & Others \\
\hline Central Asians & 57 & 20.2 & 22.8 & 74.6 & 8.2 & 17 \\
\hline Kazakhstan & 40 & 40 & 20 & 63.1 & 23.7 & 13.2 \\
\hline Kyrgyzstan & 48 & 26 & 26 & 64.9 & 12.5 & 22.6 \\
\hline Tajikistan & 59 & 11 & 30 & 79.9 & 1 & 19.1 \\
\hline Turkmenistan & 69 & 13 & 18 & 85 & 3 & 12 \\
\hline Uzbekistan & 69 & 11 & 20 & 80 & 2 & 18 \\
\hline Russia & 84 & $12 *$ & 4 & 79.8 & $12.1 *$ & 7.1 \\
\hline
\end{tabular}

Russians, 4.4 and 0.6 million, respectively, and both choose to have two official languages, titular and Russian language.

The Ukrainian and Belarussian languages are close to Russian. In Azerbaijan, there has been a strong decline in the use of the Russian language, which is discouraged by the Azerbaijani government ${ }^{15}$ although it is still widely used in Baku, and there have been increases in the number of schoolchildren studying Russian since 2013. ${ }^{16}$

\subsubsection{Supply chains and specialization}

The Soviet system was built upon upstream-downstream supply chains, often crossing republic borders several times. Not only is redeveloping or retooling industries difficult and costly, but also the development of new ties is expensive. Products will have to be redesigned, new relationships forged (which can be risky) and new contracts developed, in countries whose legal and institutional background may not be the most business-friendly.

Patterns of specialization of production may help determine who trades with whom. During most of the Soviet era, industrialization was planned centrally from Moscow, and the specializations of individual regions were planned to complement one another. Djankov and Freund (2002a) shows estimates of the orientation of exports by the various USSR republics in 1990 and 1996. In 1990, all republics (excluding Russia) traded overwhelmingly (80-90\%) with other former Soviet republics, with around half of that trade, on average, being with Russia itself. Table 3 shows the mutual trade specializations in the Soviet era. Comparison of main type of commodities which were traded show that the same countries still specialize in trading similar goods in mutual trade.

\footnotetext{
15 http://www.publicdialogues.info.

16 https://ge.boell.org/en/2017/10/16/betwixt-and-between-reality-russian-soft-power-azerbaijan.
} 
Looking at trade between the Central Asian economies (relatively less developed, but resource rich) and Russia, typically, Central Asia tended to be trading either relatively low skill-intensive products or raw (extracted but unprocessed) materials, while, in return, the majority of Central Asian imports from Russia are processed or refined (finished or intermediate) types of goods. Dowling and Wignaraja (2006) state 'During the Soviet period, the Central Asian republics were required to supply raw materials, energy, and intermediate inputs to the Russian Federation as part of the integrated production system. The Russian Federation supplied finished manufactured goods to the Central Asian republics and other regions.' One final feature of the Soviet type of trading was that the Central Asian states were net importers while Soviet Russia was a net exporter. During the Soviet era, this might have been seen as a pattern of subsidy from the more developed center to the poorer periphery, as a means of attempting to maintain the Union. According to Fisher (1994), Russia's inter-republic trade balance was positive with $+9 \%$ of Net Material Product at domestic prices, while the balance was negative $(-20 \%)$ for Central Asian countries in 1987.

\subsection{Policy-related dyadic factors: passive and active}

We are particularly interested in whether policy is having an effect in reversing or slowing the decline of bilateral trade between Russia and the CIS + region. However, even after taking account of non-policy factors above, it is still the case that policy may be affecting trade in ways that are not deliberate.

\subsubsection{Passive policy: persistence of use of Soviet era standards}

Unlike the Baltic States, which entered the EU, and with the very recent exceptions of Ukraine and Moldova (as part of their recent Deep and Comprehensive FTA agreements with the $\mathrm{EU}^{17}$ ), Russian and CIS+ products have continued to lagged far behind similar products offered by Japan, USA or the EU in terms of quality: partly because their goods continue to be based on in the industries inherited from the USSR and still use the Soviet production standards (GOSTs). The CEPS (2006) report for the EU on Ukrainian-EU trade emphasized the importance of re-branding the Ukrainian economy, associated with the adoption of EU standards, which are much more widely trusted outside the former Soviet Union. Speaking of GOSTs, those production standards were established during Soviet years and for Soviet industries. Since the independence of countries which are now part of the CIS+, there has been a general failure to update GOSTs to match international production standards. Therefore, many products produced under the GOSTs would only be recognized in other CIS+ countries. A World Bank (2012) study that quantifies the possible impact of further Eurasian Integration of the regions also finds that having GOSTs creates one of major obstacles for the members to trade with other

\footnotetext{
17 Along with Georgia, Ukraine and Moldova are seen by the EU as the three Deep and Comprehensive FTAs, see http://www.3dcftas.eu/.
} 
Table 3 Trade between Soviet Central Asia and Russia in 1989 (in millions of US dollars). Source: USSR statistics agency, Goscomstat. Values have been converted from 1989 Soviet rubles to US dollars in 2007

\begin{tabular}{lrrrrrl}
\hline & Kazakhstan & Kyrgyzstan & Tajikistan & Turkmenistan & Uzbekistan & Russia \\
\hline Oil and gas & 1504 & 5404 & 5256 & 4595 & 18,675 & 181,579 \\
Electric energy & 535 & 343 & 345 & 101 & 1131 & 3243 \\
Coal & 199 & 43 & 90 & 13 & 219 & 706 \\
Other energy & 1 & 48 & 10 & 898 & 61 & 520 \\
Ferrous metals & 1256 & 0 & 0 & 0 & 0 & 13 \\
Nonferrous metals & 350 & 218 & 149 & 144 & 842 & 9090 \\
Chemicals & 2200 & 125 & 295 & 11 & 521 & 3740 \\
Machine building & 7018 & 476 & 483 & 292 & 1461 & 13,528 \\
Wood \& paper products & 1060 & 1255 & 1158 & 1373 & 4617 & 65,692 \\
Construction materials & 422 & 166 & 174 & 135 & 713 & 2703 \\
Light industry & 4297 & 102 & 75 & 71 & 261 & 1829 \\
Food industry & 2395 & 1230 & 1090 & 1025 & 3774 & 37,126 \\
Other industries & 576 & 844 & 734 & 802 & 2526 & 30,343 \\
Agricultural products & 499 & 111 & 139 & 251 & 521 & 3793 \\
Transport services & 401 & 315 & 335 & 245 & 1667 & 7881 \\
Memorandum & 102 & 130 & 181 & 125 & 358 & 1373 \\
\hline
\end{tabular}

neighboring regions (i.e., with the EU and China). Central Asia, for example, could only offer the same type of goods (materials and minerals in raw form or agricultural and intermediate goods that required further processing) that they had produced in the late Soviet era. However, to bring their products to the shelves required further processing (i.e., large investments to build new industries) for which neither Central Asia nor Russia had capital in the early stages of early transition. Since 2000, an increase in World prices and demand for energy resources allowed CIS+ members and Russia to increase sales to other CIS+ markets without necessarily intensifying skill and knowledge use. Attempts to develop more skill-intensive production are still hampered by corruption, political, managerial and marketing inefficiencies (Collins 2009).

\subsection{Active policy to reverse post-colonial reorientation: regional trade agreements}

Djankov and Freund (2002a) argue that the imposition of tariffs between former Soviet republics played a significant role in the early post-Soviet trade collapse. They document this by comparing the value of trade in a gravity model between Russian regions with that between Russian regions and other former Soviet republics: while there was no evidence of bias in 1987, by 1996 the regions traded 60\% more with each other than with non-Russian republics. In Djankov and Freund 
(2002b), they attribute this primarily to tariffs, estimating a short-run tariff elasticity (in 2004 ) of -1 , rising to -1.7 by 2006 .

In response to the early disintegration shock, there has been an emphasis on regional trade agreements, as well as other organizations which might boost trade. Most CIS+ members have by now joined the WTO (exceptions are Belarus, Uzbekistan, Turkmenistan and Azerbaijan). ${ }^{18}$ Regional trade agreements and organizations play important role to boost trade. In that sense, in post-Soviet years, newly established Central Asian countries and Russia made a number of agreements with each other and formed several important organization to solve regional trade issues. However, the Central Asian regional trade partnerships were more formality than solution, and over time become complex, with 'hubs' and 'spokes' creating additional obstacles for internal and international Central Asian trade. Acharya et al. (2011) point out that Regional Trade Agreements formed in the Central Asian region are mainly with CIS countries, and show the significance of historical colonial and cultural ties. Real regional integration actions began with the establishment of the Eurasian Custom Union (EACU) between Kazakhstan, Russia and Belarus, which is intended to be the first step toward forming 'A Common Economic Space': a common supranational system of trade and tariffs connecting all CIS countries. Ukraine which was originally seen as a member of EACU, but subsequently tilted more toward the EU. Most of the presented RTAs have had relatively little practical importance (Acharya et al. 2011) but a major exception is probably the EACU which has 'partially' unified the customs of Kazakhstan, Russia and Belarus. The EACU produced a rather temporary boost to trade for the Central Asian and Russian economies and, according to the World Bank (2012) and Kassenova (2012), mainly benefited Russia.

\section{Data and empirical models}

\subsection{Data}

We utilize a panel of 37 countries, over the years 1995-2011 inclusive. Our data are bilateral by country pairs, and covers Russia and 9 other CIC+ countries, as well as two former Soviet republics which are not associated with the CIS, and 25 other countries (see Table 1 for the list of countries). Overall, the sample has 23,273 observations, although we had slightly fewer than this for logs of trade flow and trade cost, which meant our sample for estimation had to be reduced. Sadly, data on 1989-1992 are either missing or if reported are unreliable; these problems also apply to the data for the period till 1994 which is characterized by hyperinflation. Bilateral trade flows in 2007 US dollars and tariff rates, effectively applied tariff rates, were obtained from WITS (www.wits.org). This contains both the COMTRADE and TRAINS bilateral databases, both of which contain some of the necessary data, as COMTRADE covers only WTO members, while TRAINS covers all CA countries,

\footnotetext{
18 The WTO list their membership on https://www.wto.org/english/thewto_e/whatis_e/tif_e/org6_e.htm.
} 
but aggregates the EU into one single region. GDP levels were obtained from the IMF's International Financial Statistics Database (www.imf.org), while geographic distances between capital cities of the countries and standard gravity dummies for common colonial history, language, borders were obtained from CEPII (www.cepii .fr). Additional dummies for landlockedness and RTA membership were constructed manually and included to the model. Further details about variables are in Table 9 in 'Appendix,' and a listing of countries and country groupings is in Table 1. Table 4 shows summary statistics for all variables.

\subsection{Estimation models}

We investigate a variety of specifications, some based upon bilateral trade flows, while others utilize the tetrad estimates of the effects of trade costs. In addition, we start incorporating a variety of dummies to model post-Soviet trade effects specifically, and we move from static models, initially, to dynamic models, to investigate stickiness of trade flows. We start with our baseline gravity model given in a loglinear form:

$$
\ln \left(X_{i j t}\right)=a_{0}+a_{1} M_{i t}+a_{2} N_{j t}+a_{3} I_{t}+a_{4} D_{i j t}+a_{5} \text { ExSoviet }_{i j}+\varepsilon_{i j t},
$$

where $\ln \left(X_{i j t}\right)$ is bilateral trade flow from $\mathrm{i}$ to $\mathrm{j}$ at time $\mathrm{t}$ (which we denote in the tables as $\ln$ (Trade Flow)), $\left(M_{i t}\right)$ is a set of exporter country-specific variables, corresponding to the monadic variable $m_{i t}$ in Eq. 3, incorporating an exporter dummy and a series of $\ln \left(G D P_{i t}\right.$ for the exporter, $\left(N_{j t}\right)$ is a set of importer country-specific dummies, corresponding to $n_{i t}$ in Eq. 4, incorporating an importer dummy and a series of $\ln \left(G D P_{j t}\right.$ for the importer, $\left(I_{t}\right)$ is a set of year dummies. ${ }^{19}$ The gravity controls, $D_{i j t}$ is a set of standard gravity controls, which are bilateral variables that include a geographic distance variable, $\ln \left(\right.$ Distance $\left._{i j}\right)$, a tariff variable, $\ln \left(1+\right.$ Tariff $\left._{i j t}\right)$, and a set of dummies to control for sharing common border ('contiguous'), landlockedness, regional trade agreement, common colony, common language and the case where $i$ and $j$ are the same country. ${ }^{20}$ We take the natural $\log$ of all continuous variables. ${ }^{21}$

Once we have carried out the baseline regression, we then incorporate a series of variables (ExSoviet) for various categories of flows among the post-Soviet republics. $^{22}$ More specifically, monadic dummy variables are dropped, as they

\footnotetext{
19 For consistency, we should be using exporter-year and importer-year dummies, as discussed in Olivero and Yotov 2012). The reason we are not doing it is because we are estimating the effect of independence on trade flows which is captured by year dummies. Thus, we use year dummies without tabulating them with exporter and importer dummies. This fact doesn't impact on our estimation results. We report the baseline regression results using exporter-year and importer-year dummies (see Table 11) which are similar either in magnitude or sign.

20 We might interpret this as a 'home bias' dummy. Anderson and Yotov (2016) stress the importance of inclusion of this dummy.

21 Note that we have dropped time-invariant factors for importer and exporter countries, as these are subsumed in exporter and importer fixed effects.

22 Note that some of these are collinear with some of the country-specific dummies, which are automatically dropped. However, the post-Soviet variables help provide a clearer picture of what is happening.
} 
Table 4 Summary statistics

\begin{tabular}{|c|c|c|c|c|c|}
\hline Variable & Observations & Mean & SD & Min & Max \\
\hline $\ln$ (Trade flow) & 19,522 & 1.91 & 3.15 & -6.91 & 13.85 \\
\hline $\ln$ (Trade cost) & 19,432 & 0.73 & 0.41 & 0.00 & 3.84 \\
\hline $\ln (\mathrm{GDP})$ & 23,273 & 5.03 & 2.24 & -0.56 & 10.24 \\
\hline $\ln ($ Distance $)$ & 23,273 & 7.89 & 0.87 & 4.38 & 9.48 \\
\hline $\ln (1+$ Tariff $)$ & 23,273 & 0.03 & 0.05 & 0.00 & 0.79 \\
\hline Contiguous & 23,273 & 0.08 & 0.27 & 0.00 & 1.00 \\
\hline RTA Between $i$ and $j$ & 23,273 & 0.53 & 0.50 & 0.00 & 1.00 \\
\hline Colony & 23,273 & 0.03 & 0.18 & 0.00 & 1.00 \\
\hline Common Language & 23,273 & 0.04 & 0.19 & 0.00 & 1.00 \\
\hline$i$ and $j$ are Same Country & 23,273 & 0.03 & 0.16 & 0.00 & 1.00 \\
\hline$i$ and $j$ Both Landlocked & 23,273 & 0.43 & 0.49 & 0.00 & 1.00 \\
\hline \multicolumn{6}{|c|}{ Country Pair Group Dummies } \\
\hline$R U S_{j-} C I S+_{i}$ & 23,273 & 0.01 & 0.09 & 0.00 & 1.00 \\
\hline$R U S_{i-} C I S+_{j}$ & 23,273 & 0.01 & 0.09 & 0.00 & 1.00 \\
\hline$S I B_{j-} S I B_{i}$ & 23,273 & 0.07 & 0.26 & 0.00 & 1.00 \\
\hline proRUS_RUS & 23,273 & 0.005 & 0.076 & 0.00 & 1.00 \\
\hline
\end{tabular}

Definitions of variables are in Table 9. Country $i$ is the exporter, and $j$ is the importer throughout the tables

are collinear with exporter and importer fixed effects. However, we keep dyadic dummy variables for Soviet metropole-CIS+ pairs $\left(R U S_{j-C} C I S+_{i}, R U S_{i-} C I S+_{j}\right.$, and proRUS_RUS) or Soviet sibling (non-metropole) country pairs $\left(S I B_{j} S I B_{i}\right)$. Hence, we are aiming to model the effects of a pair of countries being various varieties of post-Soviet metropole/siblings.

We use the generalized least squares (GLS) estimator and all regression results reported in Tables 5, 6 and 7 are produced with GLS. As robustness checks, we employ alternative estimators, which are summarized in Table 12 in 'Appendix,' and confirm that our estimates are robust. ${ }^{23}$

To accompany the baseline estimation (based on log trade flows), we replace the dependent variable with the tetradic trade cost variable $\left(\tau_{(i l)(j k) t}\right.$ in (10)). We note in calculating tetrads we used the UK and Germany as our reference exporter and importer countries, and assuming that the elasticity of substitution is about the same as the estimates coefficient on $\ln (1+$ Tariff $),{ }^{24}$ in order to get tariff-equivalent level of bilateral trade costs. Thus, our baseline trade cost equation is

\footnotetext{
${ }^{23}$ The baseline estimations in Table 12 are with Poisson pseudo-maximum likelihood (PPML) on the lines of Silva and Tenreyro $(2006,2011)$ and two-stage least squares. All other methods confirm the GLS results. The one exception is PPML, which provides some unexpected signs for tariffs and the colony variable but on average higher coefficient estimates. We think this is either due to inclusion of zero trade flows, or due to its nature of being a semilog type of method, while all the others are log-log.

${ }^{24}$ Note that, since trade flows are in value terms, the coefficient on $(1+$ Tariff $)$ is an estimate of $1+\sigma$.
} 
Table 5 Regressions with trade flows

\begin{tabular}{|c|c|c|c|c|}
\hline \multirow[t]{2}{*}{ Variables } & (1) & (2) & (3) & \\
\hline & $\ln$ (Trade flow) & $\ln$ (Trade flow) & $\ln$ (Trade flow) & $\ln$ (Trade flow) \\
\hline Year/country dummies & Yes & Yes & Yes & Yes \\
\hline $\ln \left(G D P_{i}\right)$ & $\begin{array}{l}0.14 * * * \\
(0.037)\end{array}$ & $\begin{array}{l}0.14 * * * \\
(0.037)\end{array}$ & $\begin{array}{l}0.14 * * * \\
(0.038)\end{array}$ & $\begin{array}{l}0.14 * * * \\
(0.038)\end{array}$ \\
\hline $\ln \left(G D P_{j}\right)$ & $\begin{array}{l}0.78 * * * \\
(0.046)\end{array}$ & $\begin{array}{l}0.78 * * * \\
(0.046)\end{array}$ & $\begin{array}{l}0.78 * * * \\
(0.046)\end{array}$ & $\begin{array}{l}0.78 * * * \\
(0.046)\end{array}$ \\
\hline $\ln ($ Distance $)$ & $\begin{array}{l}-1.12^{* * * *} \\
(0.081)\end{array}$ & $\begin{array}{l}-1.03^{* * *} \\
(0.075)\end{array}$ & $\begin{array}{l}-1.02^{* * *} \\
(0.076)\end{array}$ & $\begin{array}{l}-1.02 * * * \\
(0.076)\end{array}$ \\
\hline Contiguous & $\begin{array}{l}0.41 * * \\
(0.143)\end{array}$ & $\begin{array}{l}0.41 * * \\
(0.145)\end{array}$ & $\begin{array}{l}0.41 * * \\
(0.146)\end{array}$ & $\begin{array}{l}0.42 * * \\
(0.146)\end{array}$ \\
\hline$i$ and $j$ Both Landlocked & $\begin{array}{l}-0.76^{* * * *} \\
(0.191)\end{array}$ & $\begin{array}{l}-0.40 * \\
(0.172)\end{array}$ & $\begin{array}{l}-0.35 * \\
(0.172)\end{array}$ & $\begin{array}{l}-0.35^{*} \\
(0.172)\end{array}$ \\
\hline $\ln (1+$ Tariff $)$ & $\begin{array}{l}-3.61 * * * \\
(0.517)\end{array}$ & $\begin{array}{l}-3.58^{* * *} \\
(0.515)\end{array}$ & $\begin{array}{l}-3.58^{* * *} \\
(0.515)\end{array}$ & $\begin{array}{l}-3.58^{* * *} \\
(0.515)\end{array}$ \\
\hline RTA Between $i$ and $j$ & $\begin{array}{l}0.41 * * * \\
(0.047)\end{array}$ & $\begin{array}{l}0.37 * * * \\
(0.048)\end{array}$ & $\begin{array}{l}0.37 * * * \\
(0.048)\end{array}$ & $\begin{array}{l}0.37 * * * \\
(0.048)\end{array}$ \\
\hline Colony & $\begin{array}{l}0.66^{* *} \\
(0.216)\end{array}$ & $\begin{array}{l}0.14 \\
(0.208)\end{array}$ & $\begin{array}{l}0.53 * \\
(0.263)\end{array}$ & $\begin{array}{l}0.51 * \\
(0.255)\end{array}$ \\
\hline Common Language & $\begin{array}{l}0.52 * \\
(0.211)\end{array}$ & $\begin{array}{l}0.24 \\
(0.181)\end{array}$ & $\begin{array}{l}0.25 \\
(0.180)\end{array}$ & $\begin{array}{l}0.24 \\
(0.180)\end{array}$ \\
\hline$i$ and $j$ are Same Country & $\begin{array}{l}4.11^{* * * *} \\
(0.295)\end{array}$ & $\begin{array}{l}3.92 * * * \\
(0.281)\end{array}$ & $\begin{array}{l}3.92 * * * \\
(0.283)\end{array}$ & $\begin{array}{l}3.93 * * * \\
(0.282)\end{array}$ \\
\hline Country pair group dumm & & & & \\
\hline$C I S+{ }_{i j}$ & & $\begin{array}{l}2.18 * * * \\
(0.179)\end{array}$ & & \\
\hline$R U S_{j-} C I S+_{i}$ & & & $\begin{array}{l}1.25 * * \\
(0.452)\end{array}$ & $\begin{array}{l}1.12 * \\
(0.475)\end{array}$ \\
\hline$R U S_{i-} C I S+_{j}$ & & & $\begin{array}{l}1.11 * * \\
(0.376)\end{array}$ & $\begin{array}{l}0.98 * \\
(0.406)\end{array}$ \\
\hline$S I B_{j \_} S I B_{i}$ & & & $\begin{array}{l}2.26 * * * \\
(0.186)\end{array}$ & $\begin{array}{l}2.27 * * * \\
(0.186)\end{array}$ \\
\hline proRUS_RUS & & & & $\begin{array}{l}0.45 \\
(0.355)\end{array}$ \\
\hline Constant & $\begin{array}{l}5.32 * * * \\
(0.843)\end{array}$ & $\begin{array}{l}2.96 * * * \\
(0.802)\end{array}$ & $\begin{array}{l}2.80 * * * \\
(0.811)\end{array}$ & $\begin{array}{l}2.77 * * * \\
(0.812)\end{array}$ \\
\hline Observations & 19,522 & 19,522 & 19,522 & 19,522 \\
\hline Number of I_ij & 1352 & 1352 & 1352 & 1352 \\
\hline
\end{tabular}

Robust standard errors in parentheses $* * * p<0.001, * * p<0.01, * p<0.05$. All regressions include year dummies. Columns 2-5 have exporter, importer and year dummies, while column 1 allows monadic group dummies. Variable definitions are in Table 9. i denotes exporter and j denotes importer 


$$
\ln \left(\tau_{(i l)(j k) t}\right)=b_{0}+b_{1} D_{i j t}+b_{2} M_{i}+b_{3} N_{j}+b_{4} I_{t}+b_{5} \text { ExSoviet }+\varepsilon_{i j t},
$$

Finally, we investigate a dynamic form of the model, following the logic of HRM (2010), in the sense that we investigate the degree of decline over time of postcolonial, and specifically post-Soviet trade flows. This is done by incorporation of a lagged dependent variable, and interactions thereof with post-Soviet dummies.

\section{Results and discussion}

\subsection{Static estimation results}

\subsection{First baseline table: trade flows}

'Appendix' Table 10 carries out estimation omitting country fixed effect dummies. While this is not generally recommended in gravity analysis (as discussed in AVW (2003)), this allows us to include time-invariant monadic characteristics (such as landlockedness) and group dummies for the CIS+ countries as importers and exporters. Hence, it confirms the impression that, even after correcting for landlocked location, the former Soviet countries are less open to trade than the average of the rest of the World, with the partial exception that they still trade relatively more with each other than with non-Soviet countries.

Table 5 shows our initial baseline estimation in terms of log trade flows, based upon (11). This shows the initial version of the static model, estimated by generalized least squares (GLS), and the effects of incorporation of various post-Soviet dyadic dummies.

The four columns of Table 5 show variants of the country fixed effects model. Note that most of the main estimated coefficients are stable and significant throughout. Country-specific, time-invariant variables cannot be included due to collinearity with the fixed effect dummies, and we have to be careful not to carry out regressions on combinations of country groupings which are collinear with either exporter or importer dummies. ${ }^{25}$

Trade flows have very stable and significant positive estimated elasticities of 0.14 with respect to exporter GDP and 0.78 with respect to importer GDP. The exporter GDP elasticity is perhaps lower than in much of the literature, indicating that larger countries do not necessarily produce a greater number of product varieties (perhaps particularly in a sample where several countries export mostly a few primary products). The (negative) distance elasticity is about 1.12, but falls to just over 1 when post-Soviet variables are included, and is consistent with much of the literature. The home country effect is very large and significant, at just over 4 , but falls just slightly

\footnotetext{
${ }^{25}$ Note that the use of country and year fixed effect dummies is still a relatively crude treatment of multilateral resistance terms - we investigate the use of exporter-year and importer-year fixed effects in Table 11 in 'Appendix.'
} 
when Soviet variables are included (since these countries have slightly higher apparent home bias than the rest of the sample). Trade is reduced when both countries are landlocked (although this effect is less when ex-Soviet variables are introduced). The elasticity with respect to $\ln (1+$ Tariff $)$ is again highly significant and virtually constant at (negative) 3.6, which is a bit lower than the average of the meta-analysis in Head and Mayer (2014), which averaged just over 5, but is nevertheless significantly higher than Djankov and Freund (2002b) estimates for the former Soviet Union only, during the early years of post-Soviet breakup. This is perhaps unsurprising: our sample has more post-Soviet countries, which have probably been starting from a level of being much less flexible in response to prices, compared to the rest of the World, but over time, flexibility will probably have increased.

Taking exponentials of the estimated parameters, a regional trade agreement (RTA between $i$ and $j$ ) consistently and significantly raises trade by about $37 \%$. Contiguity consistently raises trade by about $40 \%$, though the significance is only moderate. Trade is reduced if both countries are landlocked. A former colonial relationship raises trade, but this again becomes insignificant once we split out CIS+ countries (columns (3)-(4) $)^{26}$.

Concerning the post-Soviet dummies, we are unfortunately only able to look at dyadic effects here (since we have exporter and importer country dummies), although simpler statistical analysis (not included here) suggests that CIS+ countries trade significantly a great deal less than other countries in our sample, and this is even more true for countries other than Russia (which has long-developed oil and gas export infrastructure). This needs to be borne in mind when looking at the country pair group dummies, applying them to various types of post-Soviet pairs. These do show raised trade between these country pairs. For example, column (2) suggests a positive coefficient of just over 2 when both countries are CIS $+\left(C I S+{ }_{i j}\right)$. Columns (3) and (4) show positive coefficients of about 2.2 between ex-Soviet siblings (other than Russia), but mostly just over 1 where one of the pair is Russia. However, it is worth bearing in mind that the colonial ties dummy is 1 between Russia and other CIS+ ties (but not between siblings): adding this to the estimated $R U S_{j-} C I S_{i}$ and $R U S_{i-} C I S_{j}$ suggests a combined metropole-sibling effect of a bit over 1.5 , so not much less than the effect between siblings. ${ }^{27}$

In column (4), we split CIS + exports to Russia between those from a group of 'pro-Russian' (at the time) countries ${ }^{28}$, and the rest, although the dummy for proRussian, while positive, is insignificant. This suggests that pro-Russian policy is not the main driver of the raised trade between ex-Soviet country pairs.

In summary, the first baseline shows poor exports generally from the ex-Soviet states (especially those other than Russia), but a tendency for persistently higher

\footnotetext{
${ }^{26}$ Note that pairs of Russia and the other CIS+countries do appear as 'colonial relationships' in the CEPII database, which we use, although ties between CIS+ siblings do not.

27 Looking at the trade effects of individual country pairs, we would need to revert to including the monadic importer and exporter fixed effect dummies. The problem with this is that these incorporate a combination of monadic effects, including multilateral resistance to trade, so that it is not easy to compare direct effects of trade costs on one pair compared to another.

28 Kazakhstan, Kyrgyzstan, Ukraine and Uzbekistan.
} 
trade between former Soviet states, compared to that with outsiders. The poor general post-Soviet export performance perhaps reflects quality compatibility issues with product standards in the rest of the World, while there are fewer compatibility issues, and greater existing ties, among former Soviet states (Fig. 3).

\subsubsection{Second baseline table: static analysis of tariff-equivalent trade costs}

Table 6 provides a set of tariff-equivalent cost effects, derived from tetrads of trade flows, as outlined in the previous sections. The setup of columns (1)-(4) corresponds to columns (1)-(4), respectively, in the first baseline Table 5, although GDP effects are excluded, as the theoretical derivation of tetrads above suggests they should not be included (in any case they were of low significance). Post-Soviet effects are included in columns (2)-(4) in this case. The elasticity of trade cost with respect to $\ln \left(1+\right.$ Tariff $\left._{i j t}\right)$ is, highly significant and constant, though perhaps surprisingly less than unity, maybe indicating a long-run tariff passthrough of less than $100 \%$. Signs of estimated coefficients are reversed compared to Table 5, since a variable which raises trade costs will lower trade flows.

As before, estimated coefficients are stable and mostly significant. The dummies on $R U S_{i-C I S}+_{j}, R U S_{j-} C I S+_{i}$ and $S I B_{j-} S I B_{i}$ suggest that trade between Russia and other CIS+ member states, and between CIS+ siblings generally carries lower trade costs compared to that with the outside World (Fig. 4).

\subsection{Dynamic estimation}

The results of four dynamic estimations are summarized in Table 7.

$$
\begin{aligned}
\ln \left(X_{i j t}\right)= & a_{0}+a_{1} \ln \left(X_{i j, t-1}\right)+a_{2} D_{i j t}+a_{3} M_{i}+a_{4} N_{j} \\
& +a_{5} I_{t}+a_{6} \text { ExSoviet }+a_{7}\left[\text { ExSoviet } \times \ln \left(X_{i j, t-1}\right)\right]+\varepsilon_{i j t},
\end{aligned}
$$

and

$$
\begin{aligned}
\ln \left(\tau_{(i l)(j k) t}\right)=b_{0} & +b_{1} \ln \left(\tau_{(i l)(j k), t-1}\right)+b_{2} D_{i j t}+b_{3} M_{i} \\
+ & b_{4} N_{j}+b_{5} I_{t}+b_{6} \text { ExSoviet }+b_{7}[\text { ExSoviet } \\
& \left.\times \ln \left(\tau_{(i l)(j k), t-1}\right)\right]+\varepsilon_{i j t},
\end{aligned}
$$

Columns (1) and (2) are estimated in terms of trade volumes, while (3) and (4) are in terms of trade costs (derived from tetrads). We note that, although gravity modeling tends not to be dynamic, there are various studies which incorporate dynamics, usually in the form of lagged terms. Pentecost and Stack (2011) used a panel cointegration approach to European integration, finding significantly stronger effects once dynamics were taken into account. Olivero and Yotov (2012) discuss time-varying characteristics. Of papers directly relevant to our modeling, HMR (2010) utilize a lagged dependent variable in explaining post-colonial adjustment rates. While Djankov and Freund (2002a, b) do not specifically use dynamics, and indeed their 


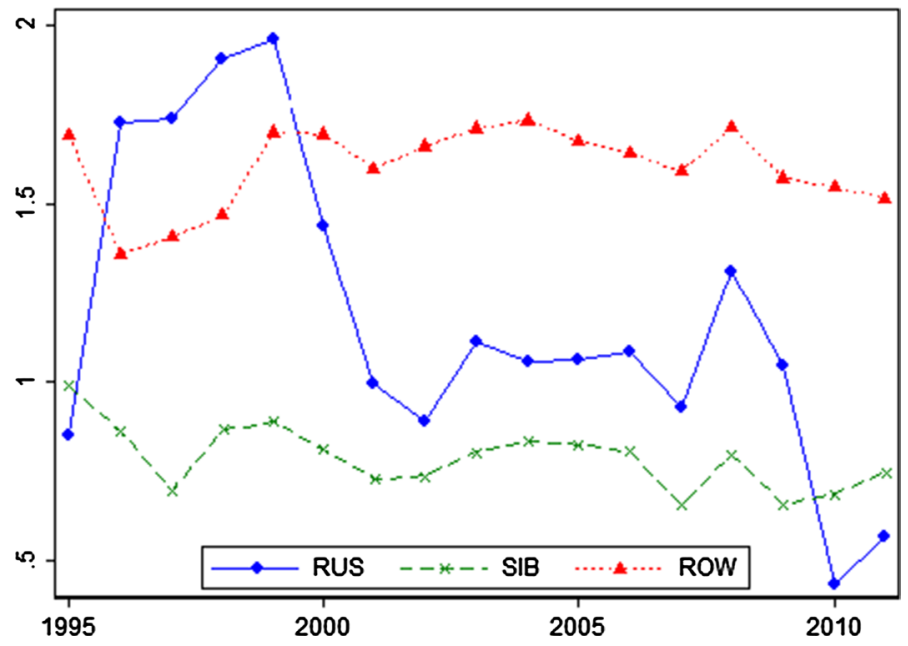

Fig. 3 Comparison of trend of metropole/sibling trade with the 'typical' metropole/colony trends from HMR (2010)

panel sample is perhaps too short for explicit dynamics, they introduce a past trade (1987 values) variable, which is positively and significantly reflected in actual trade flows. We are working with a much longer panel than these latter two papers, and so are able to look in more detail at the dynamics of adjustment.

Column (1) shows the simpler version of our model in terms of trade flows. There is just one lagged dependent variable, lagged trade flow, with a coefficient of 0.84 , which implies a mean lag of 6.25 years. ${ }^{29}$ Also, parameter estimates for the independent variables should be increased by a factor of $\frac{1}{1-0.84}=6.25$ to gain long-run steady-state effects. These are shown in Table 8. The long-run exporter and importer GDP elasticities are 0.44 and 1, while the long-run distance elasticity is -0.94 , not far from unity. The long-run elasticity with respect to $1+$ Tariff is -5.8 , confirming that trade is much more price elastic in the longer run. All of these effects are significant. The home country bias (' $i$ and $j$ are same country') parameter has a long-run value of 4 . Contiguity and RTAs seem to have only a small and borderline significant effect, while exporter landlockedness is significant and negative. The various dummies are constructed so that the CIS+ dummy includes Russia, while the siblings are all CIS+ countries excluding Russia. Russia exports significantly more than would otherwise be expected to other CIS+ countries $\left(\operatorname{RUS}_{i-} C I S+_{j}\right)$, while trade between ex-Soviet siblings is also significantly raised.

Table 7 column (2) introduces interaction terms between lagged trade and various former Soviet variables. Note that the non-dummy variables from column (1) are barely changed. What this model does allow us to do is to see whether there is any greater stickiness in trade for the former Soviet countries compared to others. Hence,

${ }^{29}$ Using the formula $\frac{1}{1-0.84}$, where 0.84 is the coefficient on the lagged dependent variable. 
Table 6 Regressions with trade costs

\begin{tabular}{|c|c|c|c|c|}
\hline Variables & (1) & (2) & (3) & (4) \\
\hline Year/Country dummies & $\begin{array}{l}\text { In(Trade Cost) } \\
\text { Yes }\end{array}$ & $\begin{array}{l}\text { In(Trade Cost) } \\
\text { Yes }\end{array}$ & $\begin{array}{l}\text { In(Trade Cost) } \\
\text { Yes }\end{array}$ & $\begin{array}{l}\text { In(Trade Cost) } \\
\text { Yes }\end{array}$ \\
\hline $\operatorname{Ln}($ Distance $)$ & $\begin{array}{l}0.32 * * * \\
(0.023)\end{array}$ & $\begin{array}{l}0.29 * * * \\
(0.021)\end{array}$ & $\begin{array}{l}0.29 * * * \\
(0.021)\end{array}$ & $\begin{array}{l}0.29 * * * \\
(0.021)\end{array}$ \\
\hline Contiguous & $\begin{array}{l}-0.11 * * \\
(0.040)\end{array}$ & $\begin{array}{l}-0.11 * * \\
(0.040)\end{array}$ & $\begin{array}{l}-0.11 * * \\
(0.040)\end{array}$ & $\begin{array}{l}-0.11 * * \\
(0.040)\end{array}$ \\
\hline$i$ and $j$ Both Landlocked & $\begin{array}{l}0.22 * * * \\
(0.055)\end{array}$ & $\begin{array}{l}0.11 * \\
(0.047)\end{array}$ & $\begin{array}{l}0.10^{*} \\
(0.047)\end{array}$ & $\begin{array}{l}0.10 * \\
(0.047)\end{array}$ \\
\hline $\ln (1+$ Tariff $)$ & $\begin{array}{l}0.62^{* * *} \\
(0.123)\end{array}$ & $\begin{array}{l}0.62^{* * * *} \\
(0.123)\end{array}$ & $\begin{array}{l}0.62^{* * * *} \\
(0.123)\end{array}$ & $\begin{array}{l}0.62 * * * \\
(0.123)\end{array}$ \\
\hline RTA Between $i$ and $j$ & $\begin{array}{l}-0.04 * * * \\
(0.012)\end{array}$ & $\begin{array}{l}-0.03 * \\
(0.012)\end{array}$ & $\begin{array}{l}-0.03 * \\
(0.012)\end{array}$ & $\begin{array}{l}-0.03 * \\
(0.012)\end{array}$ \\
\hline Colony & $\begin{array}{l}-0.21 * * * \\
(0.062)\end{array}$ & $\begin{array}{l}-0.05 \\
(0.056)\end{array}$ & $\begin{array}{l}-0.15^{*} \\
(0.074)\end{array}$ & $\begin{array}{l}-0.15^{*} \\
(0.070)\end{array}$ \\
\hline Common Language & $\begin{array}{l}-0.16^{* *} \\
(0.060)\end{array}$ & $\begin{array}{l}-0.07 \\
(0.049)\end{array}$ & $\begin{array}{l}-0.07 \\
(0.049)\end{array}$ & $\begin{array}{l}-0.07 \\
(0.049)\end{array}$ \\
\hline$i$ and $j$ are Same Country & $\begin{array}{l}-1.14^{* * *} \\
(0.084)\end{array}$ & $\begin{array}{l}-1.08 * * * \\
(0.079)\end{array}$ & $\begin{array}{l}-1.08 * * * \\
(0.080)\end{array}$ & $\begin{array}{l}-1.08 * * * \\
(0.080)\end{array}$ \\
\hline \multicolumn{5}{|c|}{ Country pair group dummies } \\
\hline$C I S++_{i j}$ & & $\begin{array}{l}-0.69 * * * \\
(0.050)\end{array}$ & & \\
\hline $\mathrm{RUS}_{j-} \mathrm{CIS}_{+_{i}}$ & & & $\begin{array}{l}-0.44 * * * \\
(0.129)\end{array}$ & $\begin{array}{l}-0.40^{* *} \\
(0.135)\end{array}$ \\
\hline $\mathrm{RUS}_{i-} \mathrm{CIS}_{+_{j}}$ & & & $\begin{array}{l}-0.41 * * * \\
(0.108)\end{array}$ & $\begin{array}{l}-0.37 * * \\
(0.117)\end{array}$ \\
\hline$S I B_{j-} S I B_{i}$ & & & $\begin{array}{l}-0.71 * * * \\
(0.052)\end{array}$ & $\begin{array}{l}-0.71 * * * \\
(0.052)\end{array}$ \\
\hline proRUS_RUS & & & & $\begin{array}{l}-0.14 \\
(0.099)\end{array}$ \\
\hline Constant & $\begin{array}{l}-3.87 * * * \\
(0.231)\end{array}$ & $\begin{array}{l}-3.13^{* * *} \\
(0.214)\end{array}$ & $\begin{array}{l}-3.09 * * * \\
(0.218)\end{array}$ & $\begin{array}{l}-3.08 * * * \\
(0.218)\end{array}$ \\
\hline Observations & 19,432 & 19,432 & 19,432 & 19,432 \\
\hline Number of $I_{-} i j$ & 1352 & 1352 & 1352 & 1352 \\
\hline
\end{tabular}

Robust standard errors in parentheses $* * * p<0.001, * * p<0.01, * p<0.05$. All regressions include exporter, importer and year dummies. Variable definitions are in Table 9 . i denotes exporter and $\mathrm{j}$ denotes importer

for example, the significant negative coefficient on Lag $\ln$ (Trade Flow) $* C I S+_{i}$ on average for the sample). Offsetting this is a significant positive coefficient on Lag In (Trade Flow) $\times R U S_{i}$. Imports by CIS + sibling countries have a small and borderline significant positive effect, indicating slowness in readjusting, while Russia has an additional positive term, indicating its import adjustment was slower still. 


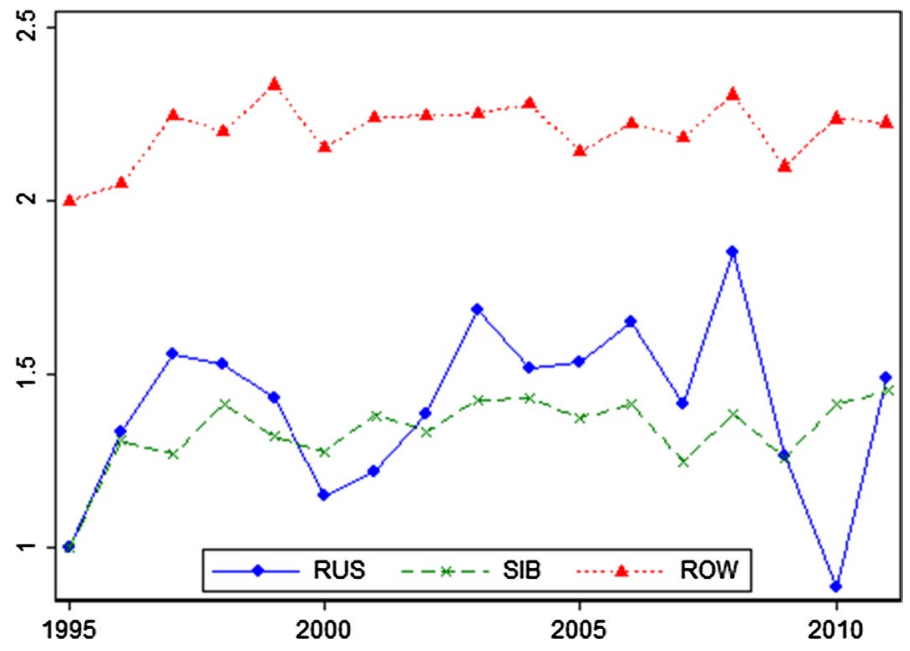

Fig. 4 Incorporating lags

It is worth noting that Russia's imports from former Soviet states showed a much faster adjustment coefficient. In terms of long-run levels, Russian imports from CIS + countries and sibling trade between former Soviet states are both significant and raised.

Table 7 columns (3) and (4) apply lagged dependent variables and various interaction terms to the tetrad trade cost estimate. Again note that, since higher costs are associated with less trade, the signs in columns (3) and (4) are reversed compared to columns (1) and (2). Column (3) just has one lagged dependent variable term, while column (4) interacts the lagged dependent variable with various dummies, to investigate the idea that trade may be stickier between some country pairs than others. Note that the estimated coefficients for distance, contiguity, $\ln (1+$ Tariff $)$ and same country are almost unchanged between columns (3) and (4). In column (3), there are negative dummies on all of our post-Soviet pairings (implying trade costs between these are reversed).

Table 7 column (4) shows interaction terms for lagged trade cost and various country and country-pair dummies. The interaction is significant and negative (trade is less sticky than the norm) for $L a g \ln ($ Trade Cost $) \times_{-} S I B_{i}$, indicating that CIS+ siblings' exports in general have adjusted faster than one might otherwise have adjusted, although where Russia is the exporter ( Lag $\ln ($ Trade Cost $\left.) \times R U S_{i}\right)$ this is exactly offset by higher stickiness for Russian exports relative to other CIS+ exports. There is a significant interaction term for trade between pro-Russian countries and Russia, indicating that trade between these pairs has been flexible.

In general, the lesson from Table 8, which summarizes the long-run steadystate values from Table 7 , is that there are significant positive long-run dummies on trade flows (or negative dummies on trade costs) between many types of former Soviet country pairs. In other words, there is a persistent long-run positive effect on trade between these, which is greater than can be explained by distance, 
Table 7 Regressions with Lags

\begin{tabular}{|c|c|c|c|c|}
\hline Variables & $\begin{array}{l}\text { (1) } \\
\ln \text { (Trade Flow) }\end{array}$ & $\begin{array}{l}(2) \\
\ln (\text { Trade Flow) }\end{array}$ & $\begin{array}{l}(3) \\
\ln (\text { Trade Cost })\end{array}$ & $\begin{array}{l}\text { (4) } \\
\ln (\text { Trade Cost })\end{array}$ \\
\hline Lag.ln(Trade Flow) & $\begin{array}{l}0.84 * * * \\
(0.009)\end{array}$ & $\begin{array}{l}0.86^{* * * *} \\
(0.009)\end{array}$ & & \\
\hline Lag.ln(Trade Cost) & & & $\begin{array}{l}0.82^{* * *} \\
(0.010)\end{array}$ & $\begin{array}{l}0.84 * * * \\
(0.012)\end{array}$ \\
\hline $\ln \left(G D P_{i}\right)$ & $\begin{array}{l}0.07 * * \\
(0.022)\end{array}$ & $\begin{array}{l}0.08^{* * * *} \\
(0.022)\end{array}$ & & \\
\hline $\ln \left(G D P_{j}\right)$ & $\begin{array}{l}0.16^{* * * *} \\
(0.047)\end{array}$ & $\begin{array}{l}0.13 * * \\
(0.049)\end{array}$ & & \\
\hline $\ln ($ Distance $)$ & $\begin{array}{l}-0.15 * * * \\
(0.015)\end{array}$ & $\begin{array}{l}-0.13 * * * \\
(0.016)\end{array}$ & $\begin{array}{l}0.05 * * * \\
(0.005)\end{array}$ & $\begin{array}{l}0.05^{* * *} \\
(0.005)\end{array}$ \\
\hline Contiguous & $\begin{array}{l}0.07 * * \\
(0.022)\end{array}$ & $\begin{array}{l}0.07 * * \\
(0.021)\end{array}$ & $\begin{array}{l}-0.02 * * \\
(0.007)\end{array}$ & $\begin{array}{l}-0.02 * \\
(0.008)\end{array}$ \\
\hline $\ln (1+$ Tariff $)$ & $\begin{array}{l}-0.93^{* * *} \\
(0.215)\end{array}$ & $\begin{array}{l}-0.95^{* * *} \\
(0.218)\end{array}$ & $\begin{array}{l}0.23 * * * \\
(0.059)\end{array}$ & $\begin{array}{l}0.23 * * * \\
(0.059)\end{array}$ \\
\hline RTA Between $i$ and $j$ & $\begin{array}{l}0.04 * \\
(0.017)\end{array}$ & $\begin{array}{l}0.08 * * * \\
(0.016)\end{array}$ & $\begin{array}{l}0.00 \\
(0.005)\end{array}$ & $\begin{array}{l}0.00 \\
(0.005)\end{array}$ \\
\hline Colony & $\begin{array}{l}0.05 \\
(0.034)\end{array}$ & $\begin{array}{l}0.07^{*} \\
(0.033)\end{array}$ & $\begin{array}{l}-0.02 \\
(0.011)\end{array}$ & $\begin{array}{l}-0.01 \\
(0.011)\end{array}$ \\
\hline Common Language & $\begin{array}{l}0.05 \\
(0.025)\end{array}$ & $\begin{array}{l}0.07^{*} \\
(0.028)\end{array}$ & $\begin{array}{l}-0.02 \\
(0.008)\end{array}$ & $\begin{array}{l}-0.02 * \\
(0.008)\end{array}$ \\
\hline$i$ and $j$ are Same Country & $\begin{array}{l}0.65 * * * \\
(0.058)\end{array}$ & $\begin{array}{l}0.59 * * * \\
(0.060)\end{array}$ & $\begin{array}{l}-0.20^{* * *} \\
(0.018)\end{array}$ & $\begin{array}{l}-0.18^{* * *} \\
(0.019)\end{array}$ \\
\hline$i$ and $j$ are Both Landlocked & $\begin{array}{l}-0.06^{*} \\
(0.029)\end{array}$ & $\begin{array}{l}-0.09^{* *} \\
(0.030)\end{array}$ & $\begin{array}{l}0.02 * \\
(0.009)\end{array}$ & $\begin{array}{l}0.02 * \\
(0.010)\end{array}$ \\
\hline Country pair group dummies & & & & \\
\hline$R U S_{j-} C I S+_{i}$ & $\begin{array}{l}0.14 \\
(0.077)\end{array}$ & & $\begin{array}{l}-0.06^{*} \\
(0.025)\end{array}$ & $\begin{array}{l}-0.13^{* * *} \\
(0.040)\end{array}$ \\
\hline$R U S_{i-} C I S+{ }_{j}$ & $\begin{array}{l}0.18 * * \\
(0.063)\end{array}$ & & $\begin{array}{l}-0.07 * * * \\
(0.020)\end{array}$ & $\begin{array}{l}-0.11^{*} \\
(0.044)\end{array}$ \\
\hline$S I B_{j-} S I B_{i}$ & $\begin{array}{l}0.32 * * * \\
(0.042)\end{array}$ & & $\begin{array}{l}-0.11 * * * \\
(0.013)\end{array}$ & $\begin{array}{l}-0.13 * * * \\
(0.016)\end{array}$ \\
\hline proRUS_RUS & $\begin{array}{l}0.11 \\
(0.072)\end{array}$ & & $\begin{array}{l}-0.03 \\
(0.022)\end{array}$ & $\begin{array}{l}-0.28 * * * \\
(0.057)\end{array}$ \\
\hline \multicolumn{5}{|c|}{ Interactions of lagged trade flow with country group dummies } \\
\hline Lag.ln(Trade Flow $) \times_{-} R U S_{i}$ & & $\begin{array}{l}0.04 * * \\
(0.014)\end{array}$ & & \\
\hline Lag.ln(Trade Flow $) \times_{-} R U S_{j}$ & & $\begin{array}{l}0.02 \\
(0.014)\end{array}$ & & \\
\hline Lag.ln(Trade Flow $) \times_{-} C I S+_{i}$ & & $\begin{array}{l}-0.05 * * * \\
(0.012)\end{array}$ & & \\
\hline
\end{tabular}


Table 7 (continued)

\begin{tabular}{|c|c|c|c|c|}
\hline \multirow[t]{2}{*}{ Variables } & (1) & 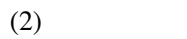 & (3) & (4) \\
\hline & $\ln$ (Trade Flow) & $\ln$ (Trade Flow) & $\ln ($ Trade Cost) & $\ln$ (Trade Cost) \\
\hline Lag.ln $($ Trade Flow $) \times{ }_{-} C I S+_{j}$ & & $\begin{array}{l}0.02 \\
(0.009)\end{array}$ & & \\
\hline Lag.ln(Trade Flow $) \times_{-} R U S_{i-} C I S+_{j}$ & & $\begin{array}{l}-0.02 \\
(0.012)\end{array}$ & & \\
\hline Lag.ln(Trade Flow $) \times{ }_{-} R U S_{j-} C I S+_{i}$ & & $\begin{array}{l}0.01 \\
(0.014)\end{array}$ & & \\
\hline Lag.ln(Trade Flow $) \times \_S I B_{j \_} S I B_{i}$ & & $\begin{array}{l}0.02 \\
(0.016)\end{array}$ & & \\
\hline Lag.ln(Trade Flow $) \times \_$proRUS_RUS & & $\begin{array}{l}0.01 \\
(0.015)\end{array}$ & & \\
\hline \multicolumn{5}{|c|}{ Interactions of lagged trade cost with country group dummies } \\
\hline Lag. $\ln ($ Trade Cost $) \times_{-} R U S_{i}$ & & & & $\begin{array}{l}0.05 * * \\
(0.016)\end{array}$ \\
\hline Lag.ln(Trade Cost $) \times \_R U S_{j}$ & & & & $\begin{array}{l}0.03 \\
(0.029)\end{array}$ \\
\hline Lag.ln $($ Trade Cost $) \times \_C I S+_{i}$ & & & & $\begin{array}{l}-0.05^{* * *} \\
(0.016)\end{array}$ \\
\hline Lag.ln(Trade Cost $) \times \_C I S_{j}$ & & & & $\begin{array}{l}0.01 \\
(0.014)\end{array}$ \\
\hline Lag.ln(Trade Cost $) \times{ }_{-} R U S i_{-} C I S+_{j}$ & & & & $\begin{array}{l}-0.05 \\
(0.044)\end{array}$ \\
\hline Lag.ln(Trade Cost $) \times \_R U S j \_C I S+_{i}$ & & & & $\begin{array}{l}-0.06 \\
(0.046)\end{array}$ \\
\hline Lag.ln $($ Trade Cost $) \times \_S I B_{j \_} S I B_{i}$ & & & & $\begin{array}{l}0.02 \\
(0.024)\end{array}$ \\
\hline Lag.In $($ Trade Cost $) \times \_$proRUS_RUS & & & & $\begin{array}{l}-0.21 * * * \\
(0.050)\end{array}$ \\
\hline Constant & $\begin{array}{l}0.28 \\
(0.243)\end{array}$ & $\begin{array}{l}0.45 \\
(0.249)\end{array}$ & $\begin{array}{l}-0.61 * * * \\
(0.048)\end{array}$ & $\begin{array}{l}-0.61 * * * \\
(0.050)\end{array}$ \\
\hline Observations & 18,079 & 18,079 & 17,989 & 17,989 \\
\hline Number of I_ij & 1350 & 1350 & 1350 & 1350 \\
\hline
\end{tabular}

Robust standard errors in parentheses

$* * * p<0.001, * * p<0.01, * p<0.05$

adjacency, language or colonial ties. The evidence is that these are, pretty much, permanent effects. By contrast, there is little specific evidence of abnormal inflexibility in trade between former Soviet country pairs. A conclusion would be that former Soviet effects are here to stay. 
Table 8 Long-run steady-state values for column 1 of Table 7

\begin{tabular}{lcc}
\hline Variables & $\begin{array}{l}\text { Dynamic regression column } 1 \\
\ln X \text { Significant values only }\end{array}$ & $\begin{array}{l}\text { Long-Run Values } \\
\ln X^{*}\end{array}$ \\
\hline Lag $\ln ($ Trade Flow) & $0.84^{* * *}$ & \\
$\ln \left(G D P_{i}\right)$ & $0.07^{* *}$ & 0.4375 \\
$\ln \left(G D P_{j}\right)$ & $0.16^{* * *}$ & 1.0000 \\
$\ln ($ Distance $)$ & $-0.15^{* * *}$ & -0.9375 \\
Contiguous & $0.07^{* *}$ & 0.4375 \\
$\ln (1+$ Tariff $)$ & $-0.93^{* * *}$ & -5.8125 \\
RTA Between $i$ and $j$ & $0.04^{*}$ & 0.2500 \\
$i$ and $j$ are Same Country & $0.65^{* * *}$ & 4.0625 \\
$i$ and $j$ are Both Landlocked & $-0.06^{*}$ & -0.3750 \\
Country pair group dummies & & \\
$R U S_{j \_C I S+}+_{i}$ & 0.14 & 0.875 \\
$R U S_{i-C I S+}$ & $0.18^{* *}$ & 0.125 \\
$S I B_{j \_} S I B_{i}$ & $0.32^{* * *}$ & 2.000 \\
proRUS_RUS & 0.11 & 0.6875 \\
\hline
\end{tabular}

Robust standard errors in parentheses $* * * p<0.001, * * p<0.01, * p<0.05$. All regressions include exporter, importer and year dummies. Variable definitions are in Table 9 . i denotes exporter and j denotes importer

\subsection{Summary of the dynamics of the various post-Soviet relationships}

In considering the dynamic estimations in the previous section, it is worth remembering that, unfortunately, data are missing for the first few years of breakup - partly due to the extreme nature of the transition of economic system, and partly due to a lack of comparability of Soviet-era trade data, particularly between republics, where trade may not have been at internationally comparable market values. ${ }^{30}$ As we discussed in Section 1.1, among Soviet republics (and unlike the other Soviet bloc states), integration was very high, and consequently the costs and trade effects of Soviet disintegration were swift and substantial (Rajasalu 1995; Sinitsina 2012). Unfortunately, our study starts after these immediate shocks.

Summarizing the dynamic estimations in Sect. 5.2, we note that the dynamic models fit considerably better than the static ones, while confirming most of the overall relationships. Mean lags are mostly around 6-7 years, so adjustment is fairly slow. Estimates of the elasticities of trade flows with respect to exporter and importer GDPs are higher in the steady state of the dynamic model (Table 8) than in the static case, with importer GDP having an elasticity of 1 , and distance being just under 1 . The elasticity with respect to $(1+$ Tariff $)$, which is a potential estimate of the

\footnotetext{
30 The same was less of a problem where the Soviet Union and satellites traded, as these typically used Western prices for exchange.
} 
Armington elasticity of substitution in trade, is -5.8 , rather than -3.6 , and is more in line with much of the recent literature.

A second point is that, in the dynamic model, we examine a variety of postSoviet dummies, both in levels terms (proportional shift adjustment of trade flows or trade costs), or in terms of interaction with the lagged dependent variable (testing for differential stickiness). In most cases, the more important effects are the levels effects, rather than the stickiness: in other words, as far as we can tell, from the sample of years available to us, there are enduring signs of raised interCIS + trade, both between Russia and the former colonies, and between colonies and siblings. There is limited evidence of difference between groups of former Soviet states, with column (2) of Table 7 indicating raised exports particularly from pro-Russian states to Russia. However, the key message is the raised overall level of intra-CIS+ trade. It is also worth noting that this is the case after taking account of adjacency, landlockedness, tariffs, RTAs and the like. In part, this may well reflect the legacy of continued planned specialization of the former Soviet republics, and the persistence of old industries, with old ties and using Soviet standards. Countries which have persisted with the old GOSTs should be seen as having chosen (albeit passively in most cases) continued integration with Russia and their CIS+ siblings, rather than the rest of the World.

Regarding stickiness (Table 7 column (2)), it does seem that Russian imports and exports in general are relatively sticky (slow adjusting). This might well be an indication of the relative inflexibility of the economy inherited from the Soviets. There is less sign of stickiness in the trade patterns of the other republics: possibly rather the reverse, maybe indicating the pressure some of these countries felt to realign and diversify their trade.

\section{Conclusion}

Being geographical neighbors to each other, at any point of history people of the various regions of the former Russian Empire and Soviet Union have been in constant interaction. This covers the periods of the Mongol Empire, Ottoman Empire, Tsarist Russia, of course, the Soviet Union, and now the fledgling Eurasian Union. Each period left its marks by creating economic, social, cultural or political ties between the peoples of the region. However, over time old ties are gradually replaced with new ties. In the current, Commonwealth of Independent States (CIS) period, Russia and the CIS states and associates have their own distinct territories, independent governing and economic systems. However, old economic ties between Russia and the CIS+ survived, rebranded or re-established from the Soviet period.

In this empirical study, we have attempted to analyze trade between the CIS+ states and Russia in the period 1995-2011. The CIS+ states became independent only in 1991. As Djankov and Freund (2002a) stress, the initial shock was very substantial, let particularly by the sudden imposition of tariff barriers, although there are serious difficulties in comparing Soviet and early post-Soviet trade 
flows, and indeed hyperinflation and various distortions continued for the first half of the 1990s. We therefore focus on the subsequent period, where, at least at first sight, there seems to have been an upturn and a recovery of the old Sovietera ties.

Our analysis of the post-1995 (i.e., post-stabilization) period is based upon comparison with the classic study of post-colonial trade persistence and decline, by HMR (2010). This study finds that in post-colonial period, colony-colonizer trade erodes by $65 \%$ in 40 years. At face value, after the initial shock of Soviet disintegration, the decline in trade between the CIS + republics seems to have been stabilized or reversed. However, this needs to be seen in the context of the sharp recoveries of many of these economies, reflecting both stabilization and oil price recovery after 1998. Hence, to examine underlying trends, we utilize the gravity concept to decompose trade patterns into monadic and dyadic components. Further, we compared dynamics of each component with dynamics of variables over time. As HMR (2010) study predicts, once we correct for monadic factors (GDP recovery), Russia-CIS + economic ties have shown an overall pattern of continuing decline over the period, marked by rising dyadic (trade cost) components.

Nevertheless, when we delve more deeply into these relationships, utilizing dynamic regressions, it becomes clear that, while a slow and sticky cooling of trade between the CIS+ republics seems to be taking place, there seems to be a long-term underlying relationship with raised trade between these countries. Moreover, this relationship seems to extend beyond what can be explained by language and colonial ties, or by attempts to renew regional trade agreements. Tentatively, we would suggest that most of these countries have not abandoned the old standards and structures of specialization which tied their economies together during and even before the Soviet era.

Open Access This article is licensed under a Creative Commons Attribution 4.0 International License, which permits use, sharing, adaptation, distribution and reproduction in any medium or format, as long as you give appropriate credit to the original author(s) and the source, provide a link to the Creative Commons licence, and indicate if changes were made. The images or other third party material in this article are included in the article's Creative Commons licence, unless indicated otherwise in a credit line to the material. If material is not included in the article's Creative Commons licence and your intended use is not permitted by statutory regulation or exceeds the permitted use, you will need to obtain permission directly from the copyright holder. To view a copy of this licence, visit http://creativecommons.org/licen ses/by/4.0/.

\section{Appendix}

See Tables 9, 10, 11 and 12 and Figs. 5 and 6 
Table 9 Description of all variables

\begin{tabular}{|c|c|}
\hline Variable Name & Variable definition \\
\hline $\ln$ (Trade Flow) & Log of Exports (US\$ Thousand) \\
\hline $\ln$ (Trade Costs) & Log of cost derived from the tetrad \\
\hline $\ln ($ Distance $)$ & Log of Weighted Distances (in kilometers) \\
\hline $\ln (1+$ Tariff $)$ & Log of 1 plus Import Tariffs (in percentages) \\
\hline Contiguity & 1 if two countries share common borders \\
\hline RTA Between $i$ and $j$ & 1 if two countries are member of same RTA \\
\hline Colony & 1 if two countries share colonial ties (CEPII listing) \\
\hline Same Language & 1 if two countries share linguistic ties (CEPII listing) \\
\hline$i$ and $j$ are Same Country & 1 if exporter and importer is the same country \\
\hline$i$ and $j$ are both landlocked & exporter and importer are landlocked \\
\hline \multicolumn{2}{|l|}{ Country group dummies } \\
\hline$C I S+{ }_{i}$ & 1 if exporter is a member of CIS + (Russia or sibling) \\
\hline $\mathrm{CIS}_{j}$ & 1 if importer is a member of CIS+ (Russia or sibling) \\
\hline$R U S \_j$ & 1 if Russia is importer \\
\hline$R U S \_i$ & 1 if Russia is exporter \\
\hline$S I B_{i}$ & 1 if exporter is CIS+ sibling member (excluding Russia) \\
\hline$S I B_{j}$ & 1 if importer is CIS+ sibling member (excluding Russia) \\
\hline \multicolumn{2}{|l|}{ Country pair group dummies } \\
\hline$C I S+{ }_{i j}$ & 1 if both exporter and importer are CIS+ members \\
\hline$R U S j \_C I S+_{i}$ & 1 if exporter is CIS+ member and importer is Russia \\
\hline$R U S i \_C I S+_{j}$ & 1 if exporter is Russia and importer is CIS+ member \\
\hline$S I B_{j \_} S I B_{i}$ & 1 if exporter and importer are former USSR member, excluding Russia \\
\hline proRUS_RUS & 1 if trade between pro-Russian former Soviet member and Russia \\
\hline
\end{tabular}

Note that the 'colony' variable is a listing of past colonial relationships from CEPII. Country pairs which are listed (in both directions) are: Austria-Croatia; France-Algeria, USA; Germany-Poland; JapanKorea; Russia-Finland, Kazakhstan, Ukraine, Uzbekistan, Kyrgyz Rep, Turkmenistan, Belarus, Lithuania, Georgia, Azerbaijan, Moldova, Tajikistan; Spain-USA; UK-UAE, USA, India 
Table 10 Regressions with trade flows (year dummies but no importer or exporter dummies)
Variables

(1)

$\ln \left(G D P_{i}\right)$

ln(Trade Flow)

$0.37 * * *$

(0.039)

$\ln \left(G D P_{j}\right)$

$0.78 * * *$

(0.029)

$\ln$ (Distance)

$-0.54 * * *$

(0.063)

Contiguous

$1.30 * * *$

(0.142)

$-0.20$

(0.171)

0.33

(0.174)

$-0.40$

(0.224)

$-3.59 * * *$

(0.497)

$0.39 * * *$

(0.046)

0.88 ***

(0.212)

0.18

(0.249)

$5.14 * * *$

(0.169)

Country group dummies
$\mathrm{CIS}_{i}$
$-1.45^{* * *}$
(0.170)
$\mathrm{CIS}_{j}$
$-0.68 * * *$
$(0.150)$

Country pair group dummies

$\begin{array}{lc}\text { CIS }+_{i j} & 2.06^{* * * *} \\ & (0.237) \\ \text { Constant } & -0.16 \\ & (0.489) \\ \text { Observations } & 19,522 \\ \text { Number of I_ij } & 1,352\end{array}$

Robust standard errors in parentheses


Table 11 Regressions with trade flows (with exp-year and imp-year dummies)

\begin{tabular}{|c|c|c|c|c|}
\hline Variables & $\begin{array}{l}(1) \\
\ln (\text { Trade Flow) }\end{array}$ & $\begin{array}{l}(2) \\
\ln \text { (Trade Flow) }\end{array}$ & $\begin{array}{l}(3) \\
\ln (\text { Trade Flow) }\end{array}$ & $\begin{array}{l}(4) \\
\ln (\text { Trade Flow) }\end{array}$ \\
\hline $\ln ($ Distance $)$ & $\begin{array}{l}-1.15^{* * *} \\
(0.086)\end{array}$ & $\begin{array}{l}-1.06^{* * *} \\
(0.078)\end{array}$ & $\begin{array}{l}-1.05^{* * *} \\
(0.079)\end{array}$ & $\begin{array}{l}-1.05^{* * *} \\
(0.079)\end{array}$ \\
\hline Contiguous & $\begin{array}{l}0.39 * * \\
(0.149)\end{array}$ & $\begin{array}{l}0.39 * * \\
(0.147)\end{array}$ & $\begin{array}{l}0.40 * * \\
(0.148)\end{array}$ & $\begin{array}{l}0.40 * * \\
(0.148)\end{array}$ \\
\hline$i$ and $j$ Both Landlocked & $\begin{array}{l}-0.79 * * * \\
(0.202)\end{array}$ & $\begin{array}{l}-0.40^{*} \\
(0.174)\end{array}$ & $\begin{array}{l}-0.36^{*} \\
(0.174)\end{array}$ & $\begin{array}{l}-0.36^{*} \\
(0.174)\end{array}$ \\
\hline $\ln (1+$ Tariff $)$ & $\begin{array}{l}-1.89 * * * \\
(0.506)\end{array}$ & $\begin{array}{l}-1.82^{* * *} \\
(0.503)\end{array}$ & $\begin{array}{l}-1.82^{* * *} \\
(0.503)\end{array}$ & $\begin{array}{l}-1.82^{* * *} \\
(0.503)\end{array}$ \\
\hline RTA Between $i$ and $j$ & $\begin{array}{l}0.25^{* * *} \\
(0.070)\end{array}$ & $\begin{array}{l}0.08 \\
(0.071)\end{array}$ & $\begin{array}{l}0.09 \\
(0.071)\end{array}$ & $\begin{array}{l}0.09 \\
(0.071)\end{array}$ \\
\hline Colony & $\begin{array}{l}0.73 * * \\
(0.230)\end{array}$ & $\begin{array}{l}0.17 \\
(0.209)\end{array}$ & $\begin{array}{l}0.55^{*} \\
(0.274)\end{array}$ & $\begin{array}{l}0.53 * \\
(0.263)\end{array}$ \\
\hline Common Language & $\begin{array}{l}0.54 * \\
(0.220)\end{array}$ & $\begin{array}{l}0.25 \\
(0.182)\end{array}$ & $\begin{array}{l}0.25 \\
(0.181)\end{array}$ & $\begin{array}{l}0.24 \\
(0.181)\end{array}$ \\
\hline$i$ and $j$ are Same Country & $\begin{array}{l}4.12 * * * \\
(0.309)\end{array}$ & $\begin{array}{l}3.91 * * * \\
(0.295)\end{array}$ & $\begin{array}{l}3.90 * * * \\
(0.300)\end{array}$ & $\begin{array}{l}3.92 * * * \\
(0.298)\end{array}$ \\
\hline \multicolumn{5}{|c|}{ Country pair group dummies } \\
\hline$R U S_{j-} C I S+_{i}$ & & & $\begin{array}{l}1.62 * * \\
(0.494)\end{array}$ & $\begin{array}{l}1.47 * * \\
(0.516)\end{array}$ \\
\hline$R U S_{i-} C I S+_{j}$ & & & $\begin{array}{l}1.49 * * * \\
(0.414)\end{array}$ & $\begin{array}{l}1.34 * * \\
(0.444)\end{array}$ \\
\hline$S I B_{j-} S I B_{i}$ & & & $\begin{array}{l}2.59 * * * \\
(0.204)\end{array}$ & $\begin{array}{l}2.60 * * * \\
(0.204)\end{array}$ \\
\hline$C I S+{ }_{i j}$ & & $\begin{array}{l}2.52 * * * \\
(0.197)\end{array}$ & & \\
\hline proRUS_RUS & & & & $\begin{array}{l}0.52 \\
(0.368)\end{array}$ \\
\hline Constant & $\begin{array}{l}9.46^{* * * *} \\
(0.853)\end{array}$ & $\begin{array}{l}6.86^{* * * *} \\
(0.784)\end{array}$ & $\begin{array}{l}6.72 * * * \\
(0.799)\end{array}$ & $\begin{array}{l}6.69 * * * \\
(0.799)\end{array}$ \\
\hline Observations & 19,522 & 19,522 & 19,522 & 19,522 \\
\hline Number of I_ij & 1352 & 1352 & 1352 & 1352 \\
\hline
\end{tabular}

Robust standard errors in parentheses $* * * p<0.001, * * p<0.01, * p<0.05$. All regressions include exporter-year and importer-year dummies. Variable definitions are in Table 9. i denotes exporter and $\mathrm{j}$ denotes importer 
Table 12 Baseline regressions with different estimators

\begin{tabular}{|c|c|c|c|c|c|}
\hline Variables & $\begin{array}{l}\text { (1) } \\
\text { GLS }\end{array}$ & $\begin{array}{l}\text { (2) } \\
\text { HSS }\end{array}$ & $\begin{array}{l}\text { (3) } \\
\text { PPML }\end{array}$ & $\begin{array}{l}\text { (4) } \\
\text { FDE }\end{array}$ & $\begin{array}{l}\text { (5) ) } \\
\text { IVLS }\end{array}$ \\
\hline $\ln \left(G D P_{i}\right)$ & $\begin{array}{l}0.29 * * * \\
(0.025)\end{array}$ & $\begin{array}{l}0.80 * * * \\
(0.016)\end{array}$ & $\begin{array}{l}0.42 * * * \\
(0.034)\end{array}$ & & $\begin{array}{l}0.31 \text { *** } \\
(0.009)\end{array}$ \\
\hline $\ln \left(G D P_{j}\right)$ & $\begin{array}{l}0.61 * * * \\
(0.019)\end{array}$ & $\begin{array}{l}0.76^{* * * *} \\
(0.017)\end{array}$ & $\begin{array}{l}0.57 * * * \\
(0.042)\end{array}$ & & $\begin{array}{l}0.60^{* * * *} \\
(0.010)\end{array}$ \\
\hline $\ln ($ Distance $)$ & $\begin{array}{l}-0.43^{* * *} \\
(0.078)\end{array}$ & $\begin{array}{l}-0.78^{* * *} \\
(0.052)\end{array}$ & $\begin{array}{l}-0.73 * * * \\
(0.131)\end{array}$ & & $\begin{array}{l}-0.43 * * * \\
(0.049)\end{array}$ \\
\hline Contiguous & $\begin{array}{l}1.34 * * * \\
(0.156)\end{array}$ & $\begin{array}{l}1.03^{* * * *} \\
(0.132)\end{array}$ & $\begin{array}{l}0.21 \\
(0.192)\end{array}$ & & $\begin{array}{l}1.34 * * * \\
(0.150)\end{array}$ \\
\hline$i$ and $j$ are Both Landlocked & $\begin{array}{l}-0.96^{* * *} \\
(0.131)\end{array}$ & $\begin{array}{l}-0.05 \\
(0.092)\end{array}$ & $\begin{array}{l}-1.28^{* * *} \\
(0.275)\end{array}$ & & $\begin{array}{l}-0.95^{* * *} \\
(0.072)\end{array}$ \\
\hline $\ln (1+$ Tariff $)$ & $\begin{array}{l}-3.78^{* * *} \\
(0.500)\end{array}$ & $\begin{array}{l}-2.36^{* * *} \\
(0.661)\end{array}$ & $\begin{array}{l}1.55 \\
(1.356)\end{array}$ & & $\begin{array}{l}-3.74 * * * \\
(0.176)\end{array}$ \\
\hline RTA Between $i$ and $j$ & $\begin{array}{l}0.43^{* * * *} \\
(0.047)\end{array}$ & $\begin{array}{l}0.54 * * * \\
(0.082)\end{array}$ & $\begin{array}{l}0.57 * * \\
(0.203)\end{array}$ & & $\begin{array}{l}0.43 * * * \\
(0.021)\end{array}$ \\
\hline Colony & $\begin{array}{l}1.13^{* * *} \\
(0.233)\end{array}$ & $\begin{array}{l}0.80 * * * \\
(0.226)\end{array}$ & $\begin{array}{l}-0.16 \\
(0.190)\end{array}$ & & $\begin{array}{l}1.13^{* * *} \\
(0.208)\end{array}$ \\
\hline Common Language & $\begin{array}{l}0.71^{*} \\
(0.283)\end{array}$ & $\begin{array}{l}0.47^{*} \\
(0.230)\end{array}$ & $\begin{array}{l}0.25 \\
(0.234)\end{array}$ & & $\begin{array}{l}0.70^{* * * *} \\
(0.190)\end{array}$ \\
\hline i are Same Country & $\begin{array}{l}5.75^{* * *} \\
(0.213)\end{array}$ & $\begin{array}{l}5.05^{* * *} \\
(0.195)\end{array}$ & $\begin{array}{l}3.61 * * * \\
(0.293)\end{array}$ & & $\begin{array}{l}5.74^{* * * *} \\
(0.244)\end{array}$ \\
\hline Change in $\ln \left(G D P_{i}\right)$ & & & & $\begin{array}{l}0.09^{* * * *} \\
(0.021)\end{array}$ & \\
\hline Change in $\ln \left(G D P_{j}\right)$ & & & & $\begin{array}{l}0.59 * * * \\
(0.066)\end{array}$ & \\
\hline Change in $\ln (1+$ Tariff $)$ & & & & $\begin{array}{l}-2.20^{* * *} \\
(0.372)\end{array}$ & \\
\hline Change in RTA & & & & $\begin{array}{l}0.19 * * * \\
(0.026)\end{array}$ & \\
\hline Constant & $\begin{array}{l}0.40 \\
(0.628)\end{array}$ & $\begin{array}{l}-0.53 \\
(0.414)\end{array}$ & $\begin{array}{l}4.19^{* * * *} \\
(1.126)\end{array}$ & $\begin{array}{l}0.03^{* * * *} \\
(0.007)\end{array}$ & $\begin{array}{l}0.40 \\
(0.394)\end{array}$ \\
\hline Observations & 19,522 & 23,273 & 23,273 & 18,079 & 19,522 \\
\hline Number of I_ij & 1,352 & & & 1,350 & 1,352 \\
\hline R-squared & & & 1.00 & & \\
\hline
\end{tabular}

Generalized least square (GLS), Poisson Pseudo-Maximum Likelihood (PPML), First Difference Estimator (FDE), Heckman Sample Selection (HSS) and Instrumental Variable Least Square (IVLS) method. Robust standard errors in parentheses $* * * p<0.001, * * p<0.01, * p<0.05$. All regressions include exporter, importer, exporter-importer and year dummies. Variable definitions are in Table 9. i denotes exporter and $\mathrm{j}$ denotes importer 
Export ratio: RU/DE (log)

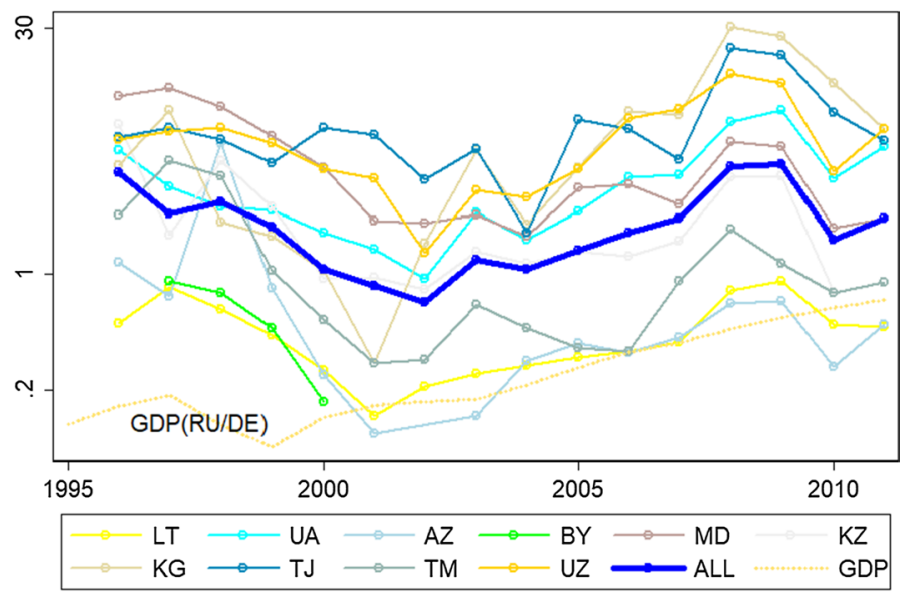

Import ratio: RU/DE (log)

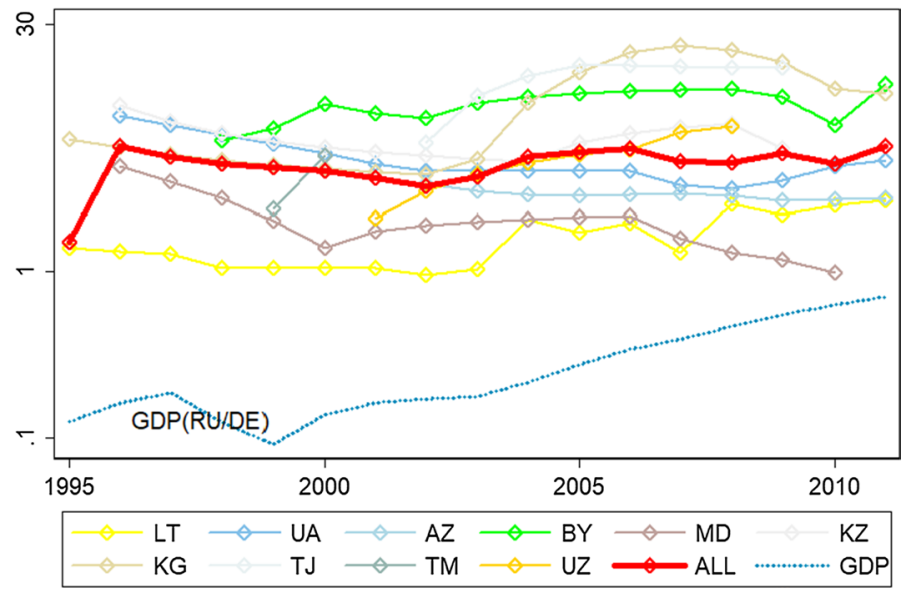

Fig. 5 Export and import ratios with Russia compared to with Germany, for selected ex-Soviet states 

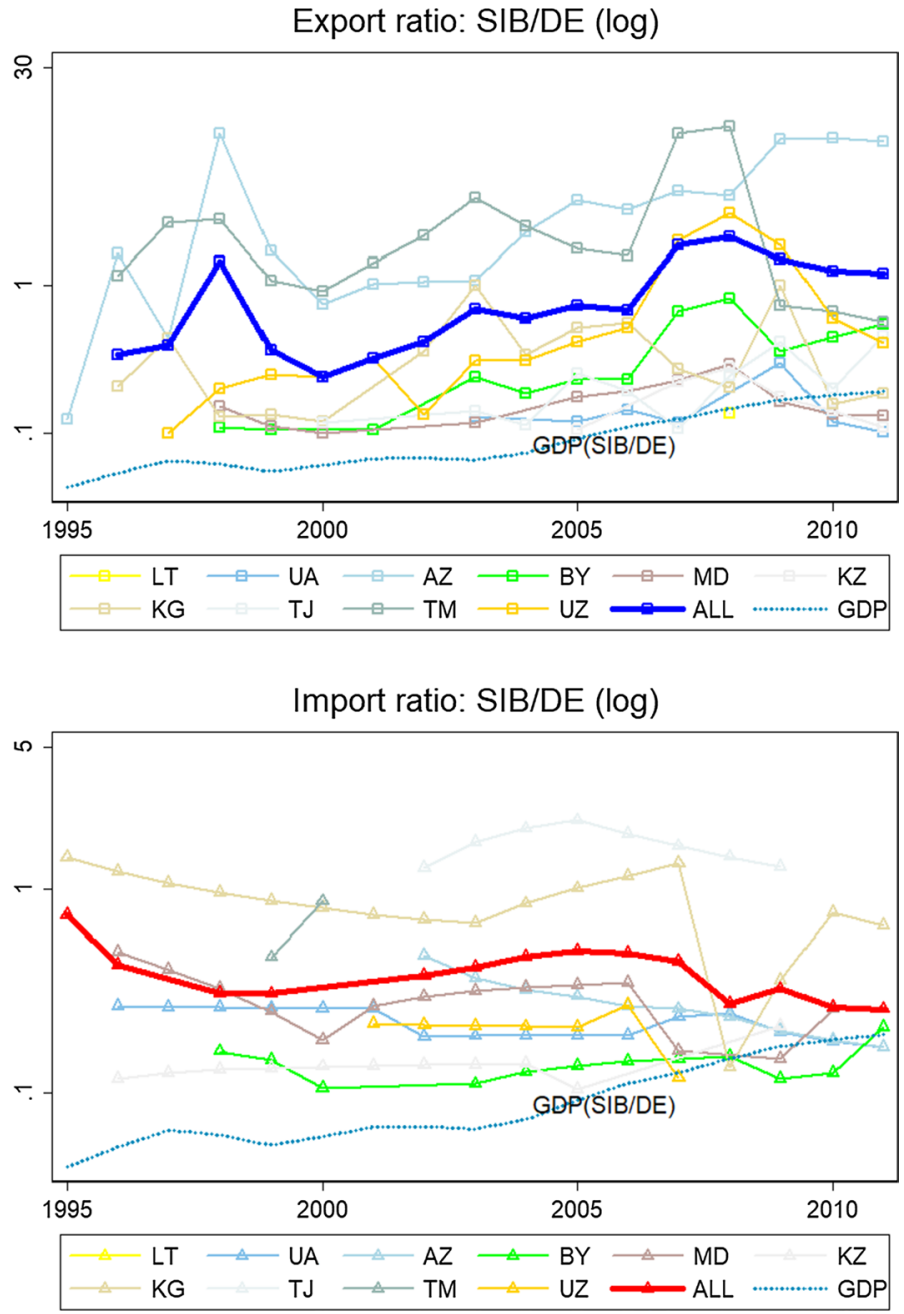

Fig. 6 Export and import ratios for ex-Soviet states with siblings compared to Germany

\section{References}

Acharya R, Crawford J, Maliszewska M, Renard C (2011) Landscape. In: Chauffour J-P, Maur J-C (eds) Preferential trade agreement policies for development. The World Bank, Washington

Anderson BA, Silver BD (1990) Trends in mortality of the Soviet population. Soviet Econ 6(1):191-251

Anderson JE, van Wincoop E (2003) Referred to as 'AvW (2003)' 'gravity with gravitas: a solution to the border puzzle'. Am Econ Rev 93(1):170-192

Anderson JE, Yotov YV (2010) The Changing Incidence of Geography. American Economic Review 100(5):2157-2186

Anderson JE, Yotov YV (2016) Terms of trade and global efficiency effects of free trade agreements, 1990-2002. J Int Econ 99:279-298

Azerbaijan State Statistical Committee: Censuses of Republic of Azerbaijan (1979, 1989, 1999, 2009). Available on Azstat.org 
Balistreri EJ, Hillberry RH (2008) The gravity model: an illustration of structural estimation as calibration. Econ Inq 46(4):511-27

Bergstrand J (1989) The generalized gravity equation, monopolistic competition and the factor-proportions theory in international trade. Rev Econ Stat 71(1):143-53

Carrere C, Grigoriou C (2007) Landlockedness, infrastructure and trade: new estimates for central Asian countries. Policy research working paper series no. 4335, The World Bank

Central Intelligence Agency (2018) CIA Factbook. Washington D.C

Chaney T (2008) Distorted gravity: the intensive and extensive margins of international trade. Am Econ Rev 98(4):1707-1721

Chen N, Novy D (2012) On the measurement of trade costs: direct versus indirect approaches to quantifying standards and technical regulations. World Trade Rev 11(03):401-414

Collins K (2009) Economic and security regionalism among patrimonial authoritarian regimes: the case of Central Asia. Eur Asia Stud 61(2):249-281

Deardorff A (1998) Determinants of bilateral trade: does gravity work in a neoclassical world? The regionalization of the world economy. National Bureau of Economic Research, Chicago University Press, Chicago, pp 7-32

Djankov S, Freund C (2002a) Trade flows in the former Soviet Union, 1987 to 1996. J Comp Econ 30:76-90

Djankov S, Freund C (2002b) New borders: evidence from the former Soviet Union. Weltwirtschaftliches Arch 138(3):493-508

Dowling M, Wignaraja G (2006) Central Asia after fifteen years of transition: growth, regional cooperation, and policy choices. Working papers on regional economic integration 3. Asian Development Bank

Eaton J, Kortum S (2002) Technology, geography, and trade. Econometrica 70(5):1741-1779

Eurasian Development Bank (2009) Eurasian integration yearbook 2009. Eurasian development bank report, Moscow

Fisher S (1994) Russia and the Soviet Union then and now. In: Blanchard OJ, Froot KA, Sachs JD (eds) The transition in eastern Europe. University of Chicago Press, Chicago

Head K, Mayer T (2014) Gravity equations: workhorse, toolkit, and cookbook. In: Gopinath G, Helpman E, Rogoff K (eds) Handbook of international economics, vol 4. Elsevier, Amsterdam

Head K, Mayer T, Ries J (2010) Referred to as 'HMR (2010)'. The erosion of colonial trade linkages after independence. J Int Econ 81(1):1-14

Helpman E, Melitz M, Rubinstrein Y (2008) Estimating trade flow: trading partners and trading volumes. Quart J Econ 123(2):441-487

Kassenova N (2012) Kazakhstan and Eurasian economic integration: quick start, mixed results and uncertain future. In: Conference presentation at annual conference of the Centre Russie/NEI in Paris, France

Limao N, Venables AJ (2001) Infrastructure, geographical disadvantage and transport costs. World Bank Econ Rev 15(1):451-479

Linn JF (2004) Economic (Dis)integration matters: the Soviet collapse revisited. Brookings, Washington

Olivero MP, Yotov YV (2012) Dynamic gravity: endogenous country size and asset accumulation. Can J Econ 45:64-92

Pentecost EJ, Stack M (2011) Regional integration and trade: a panel cointegration approach to estimating the gravity model. J Int Trade Econ Dev 20(1):53-65

Peyrouse S (2008) The Russian minority in Central Asia: migration, politics, and language. Working paper no. 297. Kennan Institute Press, Washington

Raballand G (2003) Why should trade between Central Asia and China continue to expand? Asia Eur J 5(2):235-252

Rajasalu T (1995) Macroeconomic stabilization and development. In: Lugus O, Hachey GA (eds) Transforming the Estonian economy. Majanduse Instituut, Tallinn, pp 16-51

Samuelson PA (1952) The transfer problem and transport costs: the terms of trade when impediments are absent. Econ J 62(246):278-304

Silva SJ, Tenreyro S (2006) The log of gravity. Rev Econ Stat 88:641-658

Silva SJ, Tenreyro S (2011) Further simulation evidence on the performance of the Poisson pseudo-maximum likelihood estimator. Econ Lett 112:220-222

Sinitsina I (2012) Economic cooperation between Russia and Central Asian countries: trends and outlook. University of Central Asia Working Paper No. 5. Bishkek, Kyrgyzstan

Publisher's Note Springer Nature remains neutral with regard to jurisdictional claims in published maps and institutional affiliations. 